\title{
13. LATE PLEISTOCENE DISSOLUTION CYCLES IN THE VANUATU REGION, WESTERN PACIFIC OCEAN ${ }^{1}$
}

\author{
J. Ignacio Martínez R. ${ }^{2}$
}

\begin{abstract}
A high-resolution record of foraminiferal fragmentation (a dissolution indicator) for the last $250 \mathrm{k.y}$. (isotopic Stages 1 to 7 ) is identified in the upper $61.9 \mathrm{~m}$ of Ocean Drilling Program (ODP) Hole 828A, west Vanuatu. This record is comparable in detail to the atmospheric $\mathrm{CO}_{2}$ record and the $\delta^{18} \mathrm{O}$ stack. Phase shifts between preservation spikes and maximum ice volumes $\left(\delta^{18} \mathrm{O}\right.$ of Globigerinoides sacculifer) are analogous to those on Ontong Java Plateau. Mass spectrometer $\left(\mathrm{AMS}^{14} \mathrm{C}\right)$ dating of a sample taken at the base of dissolution cycle B1 and the position of the last glacial maximum indicates a lag in time of $\sim 8$ k.y. in the Vanuatu region for the last glacial termination. When dissolution spikes are compared with minimum ice volumes there is no phase shift for the last two glacial terminations. The difference between Vanuatu and Ontong Java Plateau may be explained by local $\mathrm{CO}_{2}$ sinks and the interplay between intermediate and deep water masses. Terrigenous input increasingly affected sediment of Hole 828A on the North d'Entrecasteaux Ridge (NDR) as it approached Espiritu Santo Island. Mud and silt suspended in mid-water flows become important after $125 \mathrm{ka}$, while turbidites bypass the New Hebrides Trench only towards the last glacial maximum (LGM). Terrigenous supply seems to affect the lysocline profile that changed from an "open ocean" to a "near continent" type, thus favoring dissolution. Fragmentation of planktonic foraminifers is a more sensitive indicator of lysocline variations than is foraminiferal susceptibility to dissolution, the foraminiferal dissolution index, the abundance of benthic foraminifers, or $\mathrm{CaCO}_{3}$ content. A modern foraminiferal lysocline for the neighboring area (between $10^{\circ} \mathrm{S}$ and $30^{\circ} \mathrm{S}$, and $160^{\circ} \mathrm{E}$ and $180^{\circ} \mathrm{E}$ ) is found at $3.1 \mathrm{~km}$ below sea level, compared to west Vanuatu where it is shallower. The past lysocline level was deeper than $3086 \mathrm{~m}$ during intervals of dissolution minima, and ranged from 2550 to $3000 \mathrm{~m}$ during intervals of dissolution maxima. The high sedimentation rates (in the order of 10 to $50 \mathrm{~cm} / \mathrm{k} . \mathrm{y}$.) found in Hole $828 \mathrm{~A}$ offer a great potential for future high-resolution studies either in this hole or other western localities along the NDR. Areas of high sedimentation near continental regions have been discarded for paleoceanographic and/or paleoclimatic studies. Nonetheless, conditions analogous to those found in Hole 828 A are expected to occur in many trench areas around the world where mid-water flows have preserved as yet undiscovered fine high-resolution sedimentary records.
\end{abstract}

\section{INTRODUCTION}

Late Pleistocene paleoceanographic studies of the western equatorial Pacific are widely available (Berger and Killingley, 1977; Berger, 1977; Wu et al., 1991). A well-established isotopic record (Shackleton and Opdyke, 1973, 1976) and the pattern of $\mathrm{CaCO}_{3}$ dissolution cycles (Thompson and Saito, 1974; Thompson, 1976) are of particular interest: they are not only of stratigraphic value, but also form the basis of intensive discussion concerning the oceanic geochemical response to $\mathrm{CO}_{2}$ change during glacial-interglacial cycles (e.g., Broecker, 1971). A time lag between the isotopic and dissolution records was observed in several equatorial Pacific cores whose water depth is near, or deeper than the lysocline (Luz, 1973; Luz and Shackleton, 1975; Shackleton and Opdyke, 1976). Maximum preservation tends to occur during deglaciations and minimum preservation tends to occur during ice build-up (for a review see Farrell and Prell, 1989). The time lag between preservation maxima and glacial terminations has been estimated to vary between 3 and 20 k.y. (Luz and Shackleton, 1975; Shackleton and Opdyke, 1976; Moore et al., 1977; Berger, 1977; Farrell and Prell, 1989; Le and Shackleton, 1992).

Most western equatorial Pacific studies concentrate on the Ontong Java Plateau north of the Solomon Islands and more recently in the Sulu Sea, where high sedimentation rates offer the opportunity to examine higher-frequency oceanographic and climatic changes (Linsley and Thunell, 1990; Kudrass et al., 1991; see Fig. 1 for the location of Ontong Java Plateau). South of these regions a few paleoceanographic studies have been undertaken (e.g., Moore et al., 1980;

\footnotetext{
' Greene, H.G., Collot, J.-Y., Stokking, L.B., et al., 1994. Proc. ODP, Sci. Results, 134: College Station, TX (Ocean Drilling Program).

${ }^{2}$ Australian National University, Department of Geology, Australian Marine Quaternary Program, GPO Box 4, Canberra ACT 2601, Australia.
}

Anderson et al., 1989) but these do not deal with dissolution. Paleotemperature estimates by Anderson et al. (1989), using the modern analog technique (MAT), are similar to CLIMAP (1981) results for the equatorial west Pacific, north of $25^{\circ} \mathrm{S}$, but are significantly different further south. Temperatures for the southern Coral Sea during the last glacial maximum (LGM) are reported by Anderson et al. (1989) to be $3^{\circ}$ to $4^{\circ} \mathrm{C}$ colder than present day, and the East Australian current may not have existed or was weaker than today.

The present study analyzes cores from Holes 828A and 832A drilled west of Vanuatu. In this region dissolution effects interfere with paleoclimatic estimates based on faunal analysis at least for interglacial periods (findings consistent with Thompson, 1976), but the high sedimentation rate in Hole $828 \mathrm{~A}$ offers great potential for studying the effects of dissolution and dissolution time lags. These cores display great differences in lithology, sedimentation rates, terrigenous content, and foraminiferal preservation. Consequently, the aim of this paper is to show these differences, to compare this information with previous results from the Ontong Java Plateau, and to discuss a possible mechanism for the dissolution cycles in the western equatorial Pacific.

\section{Dissolution Cycles}

Dissolution of planktonic foraminifers in the deep sea has been studied extensively (Berger, 1968, 1970; Thompson and Saito, 1974; Shackleton and Opdyke, 1976; Thunell, 1976; Thunell et al., 1992), and the dissolution pattern through the Pleistocene is well established for the equatorial Pacific. Dissolution fluctuates with glacial and interglacial periods (Arrhenius, 1952; Hays et al., 1969), and generally is greatest during interglacials (odd-numbered isotopic stages). This may provide a basis for regional correlation (Thompson and Saito, 1974). As mentioned above, comparison of carbonate records with $\delta^{18} \mathrm{O}$ isotopic records show regional variations of their phase 


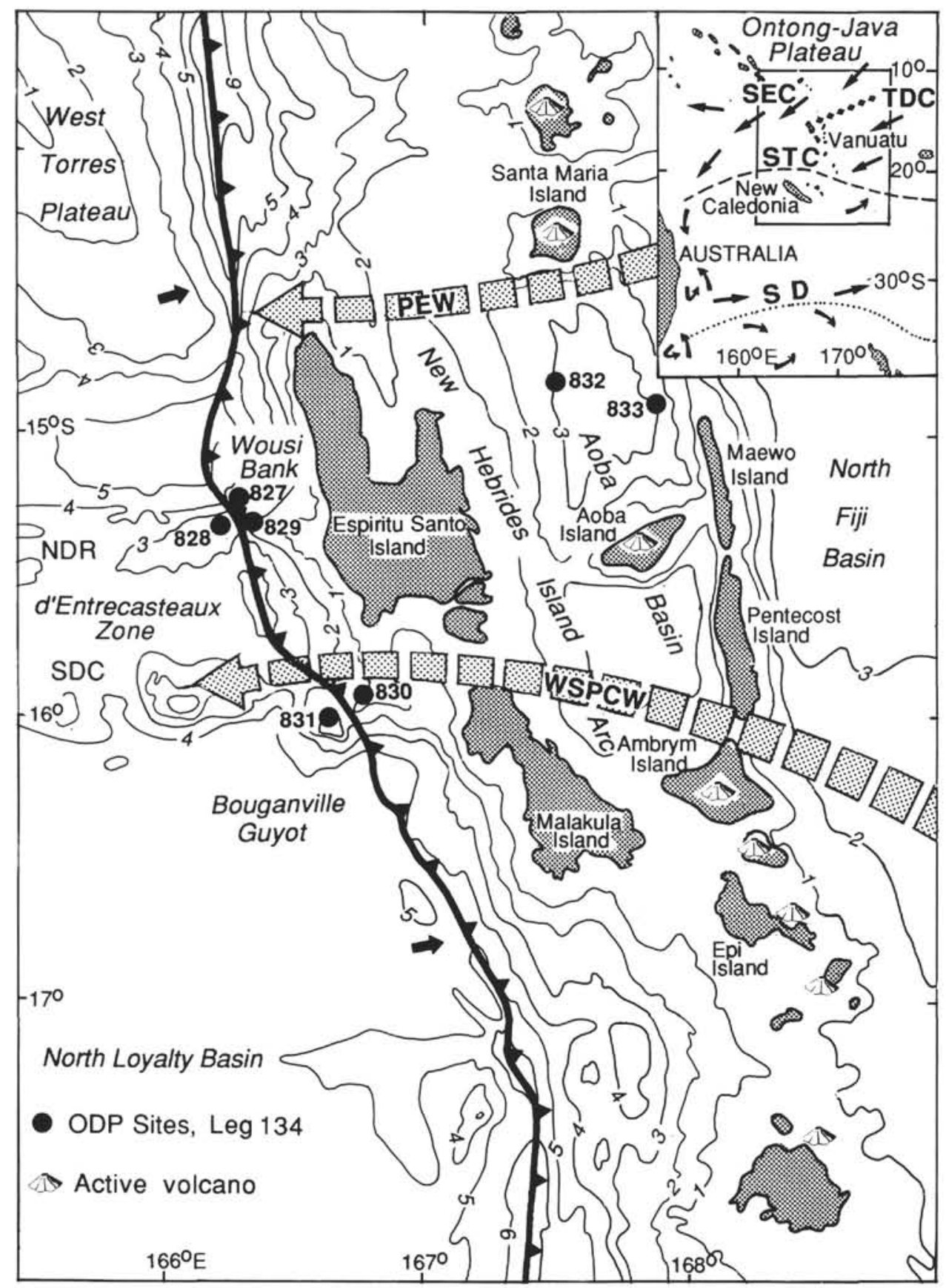

Figure 1. Location map and selected oceanographic features. Note the location of Site 828 west of the North New Hebrides Trench. Surface currents (insert, based on Rotschi and Lemasson, 1967): SEC = South Equatorial Current, $\mathrm{TDC}=$ Trade Drift Convergence, $\mathrm{STC}=$ Southern Tropical Convergence, $\mathrm{SD}=$ Subtropical Divergence. Water masses pathway (after Tomczak and Hao, 1989): PEW = Pacific Equatorial Water, WSPCW = West South Pacific Central Water. Bold line with teeth $=$ New Hebrides Trench, NDR $=$ North d'Entrecasteaux Ridge, SDC $=$ South d'Entrecasteaux Chain. Bathymetry in kilometers.

relationships; however, carbonate maxima and minima often correspond to transitional stages in the climatic cycles rather than to glacial maxima or minima (for a review see Moore et al., 1977; Farrell and Prell, 1989). Lags between the isotopic and the dissolution curves show geographical variations that prevent correlation beyond a local region (i.e., the equatorial Pacific).

Three different criteria are used to define the lag time: (1) the difference in age between glacial terminations (the mid-point between the maximum and minimum ice volumes from the $\delta^{18} \mathrm{O}$ record) and the mid-point between dissolution minima and maxima (e.g., Luz and Shackleton, 1975); (2) the difference between ice volume minima and dissolution maxima (Le and Shackleton, 1992); and (3) the difference between ice volume maxima and dissolution minima (e.g., Moore et al., 1977). Furthermore, differences in sedimentation rates, stratigraphic resolution, and techniques applied to the study of different cores may influence the accuracy of the recorded time lag between these geochemical events. Even the $\delta^{18} \mathrm{O}$ record is modified by dissolution in such a way that "climate optima" (as defined by the 
lightest $\delta^{18} \mathrm{O}$ values) tend to shift toward preservation spikes, while apparent "glacial maxima" (characterized by the heaviest $\delta^{18} \mathrm{O}$ values) shift toward dissolution spikes (Wu and Berger, 1989; Wu et al., $1990,1991)$

\section{METHODS}

Hemipelagic sediments recovered from Holes $828 \mathrm{~A}$ and $832 \mathrm{~A}$ were sampled because they appeared to be less affected by turbidites and volcanic ash than other ODP cores from Leg 134 (Fig. 1 and Table 1). Hole 831A from the Bouganville Guyot, in spite of being dominated by pelagic material, was found to be "soupy" in character (Collot, Greene, Stokking, et al., 1992), and therefore was not studied. High terrigenous and volcanic content, as in sediments of Hole 828A, are generally unsuitable for paleoceanographic studies (Ruddiman, 1977). However, good information was obtained by careful sampling above turbidite sequences, where pelagic sediments dominate. Kudrass et al. (1991) took a similar approach for the Sulu Sea, where hemipelagic layers are interbedded between turbidites protecting them from bioturbation. As shown below, sedimentation rates at Hole $828 \mathrm{~A}$ vary from $10 \mathrm{~cm} / \mathrm{k}$.y. to more than $50 \mathrm{~cm} / \mathrm{k}$.y., which means that a sample $2 \mathrm{~cm}$ thick represents 40 to $200 \mathrm{yr}$. These figures may be lower (excluding any unrecognized hiatus or reworking) if we consider the episodic character of sedimentation (Dott, 1983). Because of the high sedimentation rate, a high-resolution record is obtained with a $50-\mathrm{cm}$ sample interval. Two hundred seventeen samples were studied for fragmentation of planktonic foraminifers, 110 for foraminiferal faunal analysis, and 31 for stable isotopes $\left(\delta^{18} \mathrm{O}\right.$ and $\left.\delta^{13} \mathrm{C}\right)$. In Hole 832A, samples beneath 30 meters below seafloor ( $\mathrm{mbsf}$ ) commonly were found barren of fossils or highly lithified. Eighty-six samples were processed from Section 134-832A-6H-1 to Section 134-832B-40R-1, and of these 66 were either barren or contained poorly preserved specimens.

Approximately 5 to $7 \mathrm{~cm}^{3}$ of each sample were treated with $3 \%$ hydrogen peroxide processed in $50-\mathrm{mL}$ jars, sieved through a $63-\mu \mathrm{m}$ mesh, then dried in an oven at $40^{\circ} \mathrm{C}$, and subsequently dry-sieved through a $149-\mu \mathrm{m}$ mesh. Approximately 300 planktonic foraminifers were obtained with a microsplitter. Accelerator mass spectrometer analyses $\left(\mathrm{AMS}^{14} \mathrm{C}\right.$ ) were obtained for two samples from Hole $828 \mathrm{~A}$. Specimens were hand-picked, washed in alcohol, and placed in the ultrasonic cleaner for less than $10 \mathrm{~s}$. Alcohol was then washed away with distilled water. Carbon dioxide was produced by reaction with concentrated phosphoric acid, and stored in glass breakseals for AMS measurement. Sample 134-828A-2H-1, 29-31 cm, provided few specimens in the fraction $>150 \mu \mathrm{m}$; therefore, additional specimens were picked from the 63- to $150-\mu \mathrm{m}$ fraction. Globigerinoides ruber and Globigerinoides sacculifer (shallow planktonic species) were combined in Sample 134-828A-2H-1, 29-31 cm, because they give similar AMS ${ }^{14} \mathrm{C}$ results (Broecker et al., 1989).

The $\delta^{18} \mathrm{O}$ record was obtained from $G$. sacculifer. Each sample comprises approximately 7 specimens, selected and cleaned using the same technique as $\mathrm{AMS}^{14} \mathrm{C}$ described above. When necessary, a needle was applied to break specimens in which the last chamber was infilled with clay lumps impossible to remove by ultrasonic cleaning. The $150-$ to $250-\mu \mathrm{m}$ fraction was selected to obtain young individuals (as they live in the upper photic zone for 7-8 days before sinking to reproduce; Erez et al., 1991), which should give sea surface $\delta^{18} \mathrm{O}$ values. Analyses were carried out using a Finnigan-MAT 251 mass spectrometer at the Research School of Earth Sciences (The Australian National University) with sample dissolution effected with an on-line "acid on individual carbonate" preparation device. Oxygen and carbon isotopic data are reported in " $\delta$ " notation relative to the Peedee belemnite (PDB) standard.

\section{Dissolution Indicators}

Dissolution intensity was assessed from fragmentation of planktonic foraminifers (Berger, 1970), the relative frequencies of solution-
Table 1. Hole locations, water depths, and last occurrence (LO) of $G$. ruber (pink variety).

\begin{tabular}{lcccc}
\hline & \multicolumn{2}{c}{ Position } & & $\begin{array}{c}\text { Water } \\
\text { depth } \\
\text { Sample }(\mathrm{cm})\end{array}$ \\
\cline { 2 - 5 } & Latitude & Longitude & $\begin{array}{c}\text { Depth of } \\
\text { G. ruber } \\
\text { LO (pink) } \\
(\mathrm{mbsf})\end{array}$ \\
\hline $134-828 \mathrm{~A}-5 \mathrm{H}-5,59-60$ & $15^{\circ} 17.34^{\prime} \mathrm{S}$ & $166^{\circ} 017.04^{\prime} \mathrm{E}$ & 3086.7 & 40.99 \\
$134-832 \mathrm{~A}-4 \mathrm{H}-1,79-81$ & $14^{\circ} 47.78^{\prime} \mathrm{S}$ & $167^{\circ} 034.35^{\prime} \mathrm{E}$ & 3089.3 & 19.30 \\
\hline
\end{tabular}

susceptible vs. solution-resistant planktonic foraminifers (Berger, 1968), the foraminiferal dissolution index (Berger, 1968), and the abundance of benthic foraminifers (Parker and Berger, 1971). These have been suggested to be reliable indicators of dissolution compared to calcium carbonate concentrations, which can be greatly affected by terrigenous dilution (Thunell, 1976). Recently, to emphasize that normally no distinction is made between rates of dissolution and state of preservation, Arrhenius (1988) showed how these indicators provide only a rough estimation of dissolution. He argued that the state of preservation may differ between two samples due to sediment-accumulation rate differences, even if the rate of dissolution is the same. Later, I shall discuss advantages and disadvantages of the different dissolution indicators in a sequence where sedimentation rates vary from low to high.

The nomenclature of Hays et al. (1969) is used here to designate dissolution (odd numbers) and preservation intervals (even numbers). It has been modified to include dissolution cycles within major intervals, as in B3 (here subdivided into A, B, and C) and B5 (subdivided into $\mathrm{A}, \mathrm{B}$, and $\mathrm{C}$ ).

Fragmentation percentage was determined by counting the number of fragments in a split sample that contained 300 or more whole planktonic foraminifers, and then dividing the number of fragments by the sum of whole planktonic foraminifers together with the number of fragments. An analogous method was used to determine the abundance of benthic foraminifers. The foraminiferal dissolution index (FDX) (Berger, 1968) provides a weighted average of the dissolution rank, as follows:

$$
\mathrm{FDX}=\sum\left(P_{i} R_{i}\right) / r_{i},
$$

where $P_{i}$ is the percentage of species $i, R_{i}$ is the rank of species $i$, and $r_{i}$ is the mean rank. The solution ranking list given by Bé (1977) is used here.

\section{REGIONAL SETTING}

In contrast to the Ontong Java Plateau, the Vanuatu region is affected by higher terrigenous sedimentation (turbidites) and volcanic ashes that easily reach the backarc, the intra-arc, and the forearc areas. In the absence of any major physiographic barrier, clastic sediments from Espiritu Santo Island are spread extensively on the neighboring seafloor. This has a major influence in the central New Hebrides forearc region where the equatorial current flows towards the southwest (Rotschi and Lemasson, 1967). The high number of cyclones in the area (Gray, 1968; Howorth and Greene, 1991) tend to sweep sediments out of the narrow continental shelf of western Vanuatu. The North d'Entrecasteaux Ridge (NDR) on the subducting plate approaches Espiritu Santo Island at a rate of $\sim 13 \mathrm{~cm} / \mathrm{yr}$ and has done so since about $0.4 \mathrm{Ma}$ (Taylor et al., this volume). Hence sedimentation at Site 828 records the transit from low to high terrigenous input during the latest Pleistocene. The Trade Drift Convergence (TDC) extends southwest-northeast (Fig. 1). This feature apparently coincides with the boundary of two important shallow to intermediate water masses: the Pacific Equatorial Water (PEW) that originates in the central Pacific, and the Western South Pacific Central Water (WSPCW), that is formed at the Subtropical Convergence in the 
southern Tasman Sea (Tomczak and Hao, 1989). These water masses have similar salinities with a maximum of $35.9 \%$ at $\sim 150 \mathrm{~m}$ to about $34.5 \%$ at $\sim 400 \mathrm{~m}$. The Antarctic Intermediate Water (AAIW) occurs at intermediate depths (500 to $1500 \mathrm{~m}$ ), whereas further below (1500 m to bottom) the Circumpolar Deep Water (CDW) crosses the area (Pacific Deep Water or PDW of Thunell et al., 1992). The CDW derives from the North Atlantic Deep Water (NADW) that mixes with Antarctic waters and is transported around the Antarctic to spread over the deep Pacific and Indian oceans (Broecker and Peng, 1982; Emery and Meincke, 1986).

\section{Hole 828A}

Hole 828A was drilled on the North d'Entrecasteaux Ridge (NDR) on a flat, terrace-like feature that projects out from a bathymetric slope, at a water depth of $3086 \mathrm{~m}$ (Table 1). Cores $139-828 \mathrm{~A}-1 \mathrm{H}$ to $-7 \mathrm{H}$ cover the upper $62 \mathrm{~m}$ of this hole. Samples were taken at intervals varying from 20 to $80 \mathrm{~cm}$ from the core top down to $62 \mathrm{mbsf}$ (Fig. 2). The interval sampled comprises lithostratigraphic Unit I which consists of a greenish gray (10Y 4/1) volcanic silt with foraminiferal sand interbeds (see Collot, Greene, Stokking, et al., 1992). Scoured bases are common within the unit while bioturbation is mainly restricted to Cores $4 \mathrm{H}$ to $7 \mathrm{H}$. Equally conspicuous is the progressive increase of $\mathrm{CaCO} 3$ from Core $5 \mathrm{H}$ to $7 \mathrm{H}$ (see Collot, Greene, Stokking, et al. 1992) and the common occurrence throughout the unit of deep benthic and planktonic foraminifers, woody material, few radiolarians, and sponge spicules. These features resemble Facies D1.2 "muddy silts" and Facies C1.1 "poorly sorted muddy sands" of Pickering et al. (1989), even though the presence of contourites is not discarded. The magnetic profile shows a normal polarity for Cores $1 \mathrm{H}$ to $7 \mathrm{H}$ suggesting that these sediments were deposited during the Brunhes Chron (Collot, Greene, Stokking, et al., 1992). At 61.9 mbsf an unconformity separates the upper Pleistocene from the lower Pliocene (Collot, Greene, Stokking, et al., 1992)

\section{Hole 832A}

Hole $832 \mathrm{~A}$ was drilled in the North Aoba Basin at a water depth of $3089.3 \mathrm{~m}$ (Fig. 1). Sampling was restricted to lithostratigraphic Unit I. Sample spacing was $40 \mathrm{~cm}$ but sometimes increased up to $150 \mathrm{~cm}$ due to the high content of volcanic ash, soupy intervals, and turbidites. Samples below 30 mbsf commonly were barren of fossils or highly lithified. Above this depth 66 of the 86 processed samples were either barren or contained poorly preserved specimens. Lithostratigraphic Unit I ( $385.6 \mathrm{~m}$ thick) is mainly sandy to clayey volcanic silts interbedded with volcanic ash layers, and is restricted to the Brunhes Chron (see Collot, Greene, Stokking, et al., 1992). This array of facies resembles volcanic sedimentation model Type III of Huang (1980), which implies closely spaced volcanic eruptions and a high sedimentation rate.

\section{RESULTS}

\section{Chronology of Hole 828A}

Based on a preliminary assessment of paleomagnetic data, and the occurrence of Globorotalia tosaensis at $61.4 \mathrm{mbsf}$, Collot, Greene, Stokking, et al. (1992) suggested that most, if not all, of the Brunhes Chron was represented in Hole 828A. Oxygen isotope data reported herein show that the upper $61.9 \mathrm{mbsf}$ includes Stages 1 to 7. G. tosaensis and other Pliocene species (e.g., Dentoglobigerina altispira altispira, Globorotalia limbata, Sphaeroidinella paenedehiscens) are iron-stained, and are believed to be reworked. Consequently, at an unconformity at $61.9 \mathrm{mbsf}$, the upper Pliocene to upper Pleistocene (up to isotopic Stages 8, and possibly part of 7) are missing.

The Pleistocene chronology of Hole $828 \mathrm{~A}$ is given by the last occurrence of $G$. ruber (pink variety) (Fig. 2B), two $\mathrm{AMS}^{14} \mathrm{C}$ dates (Fig. 2B, Table 2), and the $\delta^{18} \mathrm{O}$ record of $G$. sacculifer (Fig. 2J,
Table 3). G. ruber (pink variety) is a reliable biostratigraphic marker that became extinct at about $120 \mathrm{ka}$ in the Indian-Pacific region (Thompson et al., 1979). In Hole 828A this event corresponds to a $\delta^{18} \mathrm{O}$ minimum of $-2.36 \%$ at approximately $40 \mathrm{mbsf}$. This minimum is assigned to isotopic Stage $5 \mathrm{e}$, and the $\delta^{18} \mathrm{O}$ data from 0 to $40 \mathrm{mbsf}$ closely follows the standard $\delta^{18} \mathrm{O}$ curve of Martinson et al. (1987). The $\delta^{18} \mathrm{O}$ record shows values that vary between $-0.61 \%$ and $-2.41 \%$ (the analysis of the whole set of samples is in progress). Interglacial Stages 1, 5, 7, and glacial Stage 6 can be seen clearly (Fig. 2J), whereas sharp divisions among Stages 2 to 4 are not possible to recognize with the present density of sampling. The $\delta^{18} \mathrm{O}$ data indicate that the LGM is at 9.49 mbsf, $1.5 \mathrm{~m}$ above $\mathrm{AMS}^{14} \mathrm{C}$ (Sample 134$828 \mathrm{~A}-2 \mathrm{H}-5,59-61 \mathrm{~cm}$ ), which gave an age of $16,420 \pm 210 \mathrm{ka}$. The isotopic maximum corresponding to the LGM is $17.6 \mathrm{ka}$ according to the prevailing astronomically tuned chronology (Martinson et al., 1987). The younger age of the $\delta^{18} \mathrm{O}$ maximum in Hole $828 \mathrm{~A}$ may reflect the difference between radiocarbon and astronomical years (about 2 k.y. duration 9 to $20 \mathrm{ka}$; Bard et al., 1990), or may be due to relatively wide spacing of $\delta^{18} \mathrm{O}$ measurements reported here. At this preliminary stage in the analysis, the position of the LGM at $9.49 \mathrm{mbsf}$ appears acceptable; greater precision is expected with a higher sample density in the $\delta^{18} \mathrm{O}$ record (work in progress). The positions of glacial Terminations $\mathrm{I}$ and II are drawn at the mid-point between $\delta^{18} \mathrm{O}$ maxima and minima.

Hole 832A in the North Aoba Basin shows similar results to those obtained from Hole 828A for the upper part of the sequence and, in spite of reworking of foraminifers and the presence of volcanic ash, it is possible to recognize Termination II (suggested by the last occurrence of the pink variety of $G$. ruber, Fig. 3). The last occurrence of $G$. ruber (pink variety), however, is not an abrupt event at $\sim 28$ mbsf, but it occurs sporadically above in very low numbers up to 19.3 mbsf. The same pattern was observed by Thompson et al. (1979) in Indian and Pacific ocean cores, where the species has been reported to range most frequently up to isotopic Stage $5 \mathrm{e}$, but in one example from the Indian Ocean ranges up to Stage 4.

\section{Dissolution}

The foraminiferal content of most samples was greatly diluted by terrigenous material, particularly in the interval between 0 and 40 mbsf in Hole 828A. Sometimes no more than 400 specimens $(>150$ $\mu \mathrm{m})$ could be recovered from $5-\mathrm{cm}^{3}$ samples.

Figure 2 shows the faunal content of Hole 828A. Plots of the most common species are arranged from left to right according to increasing dissolution resistance and are compared against the percentage of fragmentation and the stable isotope record. Fragmentation as well as the percentages of benthic foraminifers show high values during interglacial Stages 1 and 5. Fragmentation also shows two peaks in the 50 - to $60-\mathrm{m}$ interval, which is assigned to interglacial Stage 7. There is some correspondence between high percentages of benthic foraminifers and high fragmentation values (Fig. 2I). Boundaries of carbonate dissolution Intervals B1 to B5 (nomenclature from Hays et al., 1969) are identified where fragmentation values change abruptly or exceed the $20 \%$ level (Fig. 2E, Table 4). This value corresponds to

Table 2. Accelerator mass spectrometer $\left(\mathrm{AMS}^{14} \mathrm{C}\right)$ datings on samples from Hole 828A.

\begin{tabular}{llcll}
\hline $\begin{array}{c}\text { Core, section, } \\
\text { interval }(\mathrm{cm})\end{array}$ & \multicolumn{1}{c}{$\begin{array}{c}\text { Specimens } \\
(N)\end{array}$} & $\begin{array}{c}\text { Size fraction } \\
(\mu \mathrm{m})\end{array}$ & $\begin{array}{c}\text { Age } \\
(\mathrm{yr})\end{array}$ & Lab no. \\
\hline 134-828A- & & & & \\
$2 \mathrm{H}-1,29-31$ & $\begin{array}{l}\sim 200 \\
(G . \text { ruber })\end{array}$ & $>150$ & $9,790 \pm 150$ & NZA 1931 \\
& $\begin{array}{l}\text { 100 } \\
\text { (G. sacculifer }) \\
2 \mathrm{H}-5,59-61\end{array}$ & $>150$ & $16,420 \pm 210$ & NZA 2037 \\
& $\begin{array}{l}\text { (G. sacculifer }) \\
\end{array}$ & & & \\
\hline
\end{tabular}




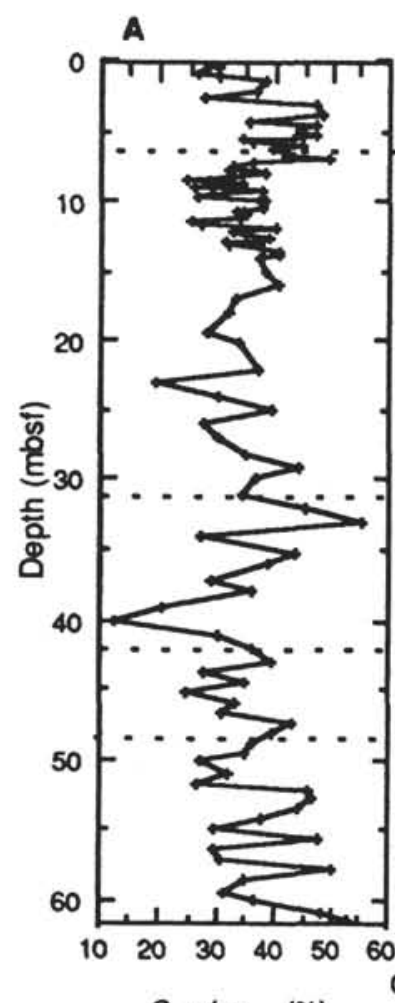

B

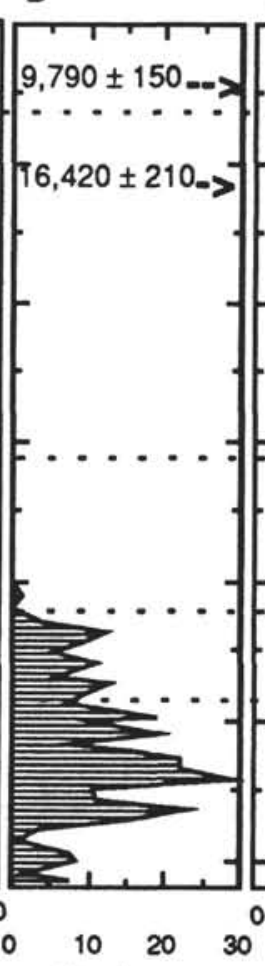

G. ruber (pinkpink+whito. 100x) c

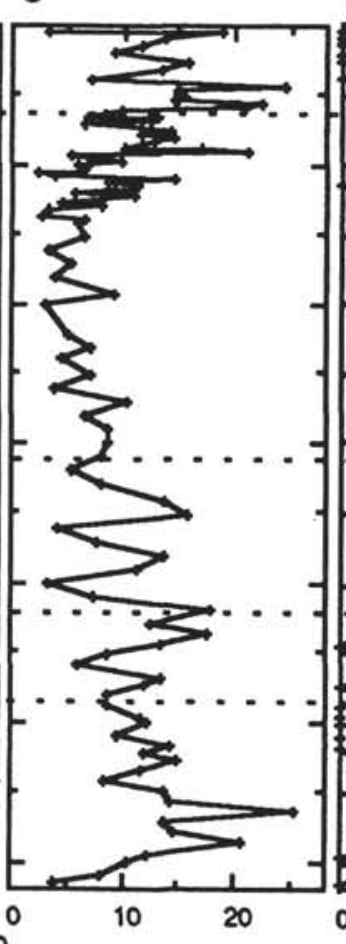

D

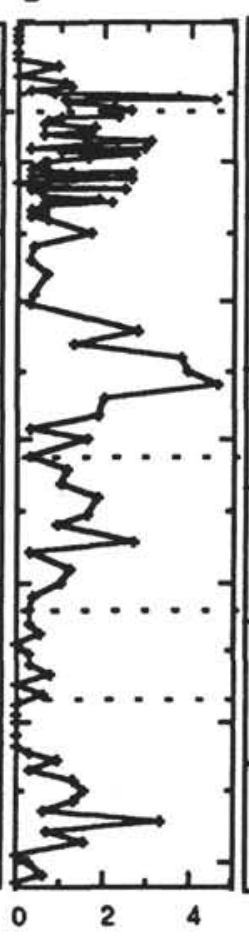

E

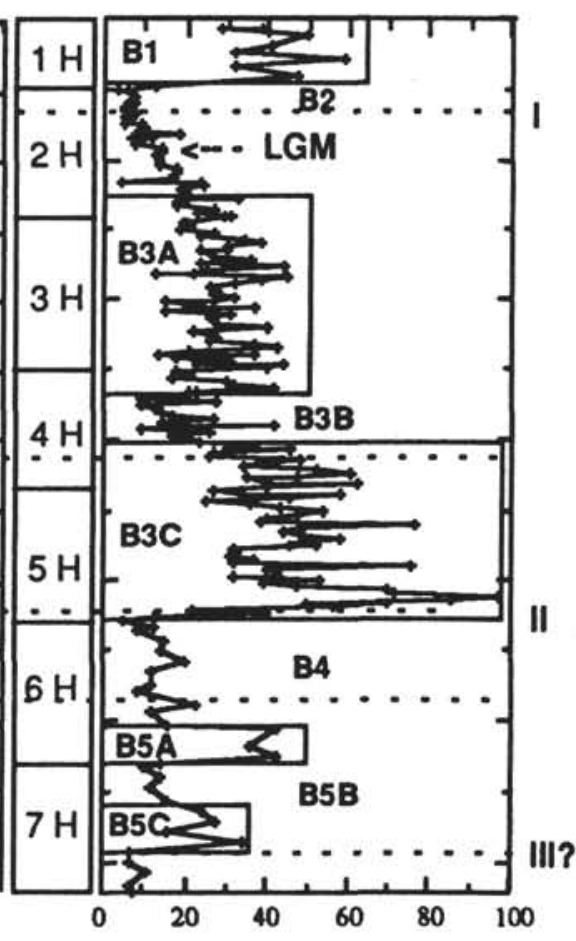

Core Fragments $(\%)$

Planktonic foraminifera
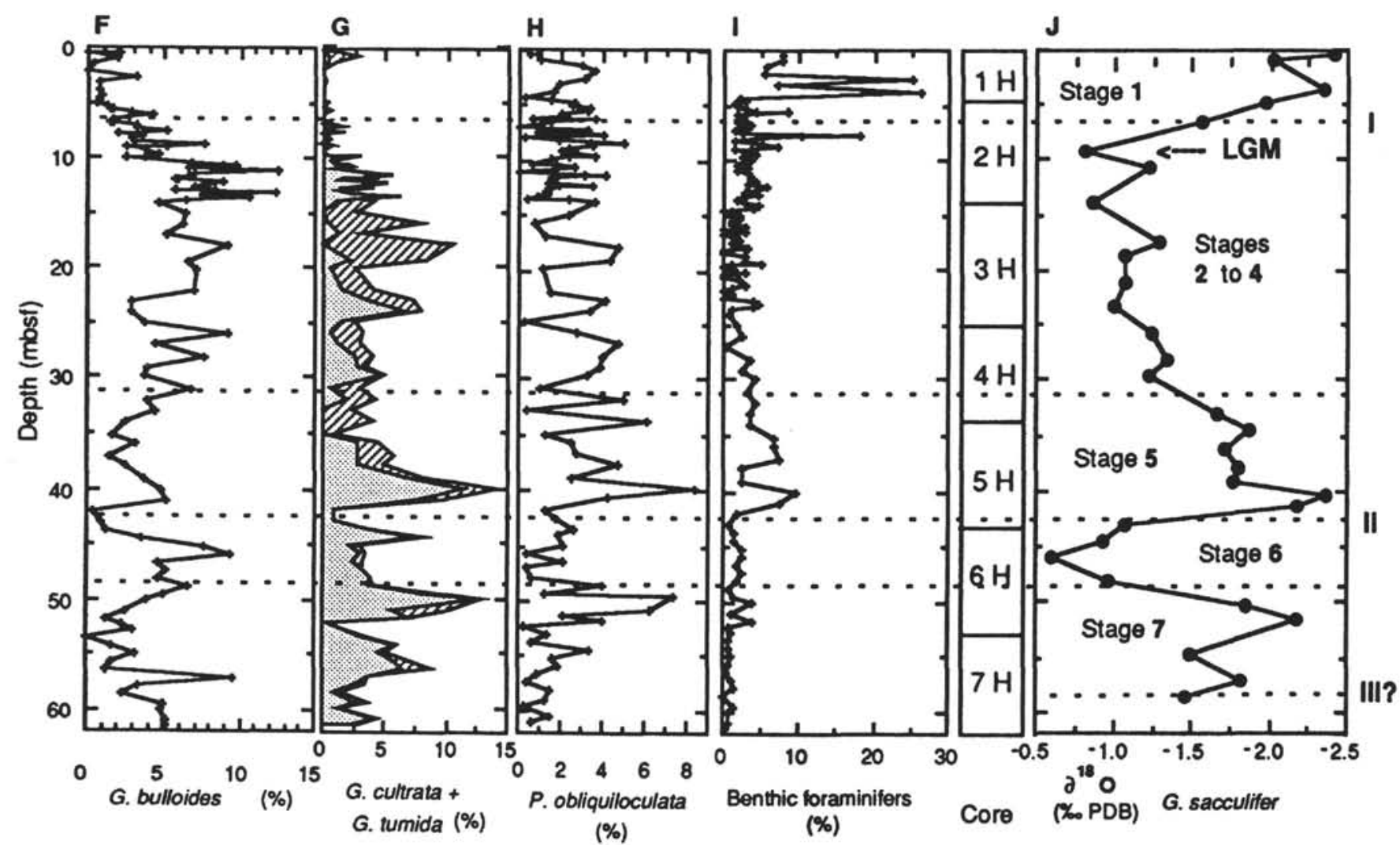

Figure 2. Hole 828A. Percentage variation of selected species of planktonic foraminifers (arranged according to their solution susceptibility) vs. the percentage of planktonic fragmentation (E), benthic foraminifers (I), and the $\delta^{18} \mathrm{O}$ record on $G$. sacculifer (J). B1 to B5 refer to dissolution cycles (nomenclature from Hays et al., 1969), and I to III? refer to glacial terminations. LGM = last glacial maximum. Note the last occurrence of $G$. ruber (pink variety) at 40 mbsf and the two $\mathrm{AMS}^{14} \mathrm{C}$ datings (panel B). 
the approximate position of the lysocline level in the region as will be shown below.

The dissolution interval boundaries in Hole 828A have a similar relationship to oxygen isotope stages as identified by Shackleton and Opdyke (1976); for example, the B1/B2 boundary is close to the Stage 1-2 boundary, and B3C/B4 is close to the Stage $5 \mathrm{e}-6$ boundary. Dissolution Intervals B3 and B5 are subdivided, in this chapter, on the same basis as major stage boundaries.

Different dissolution indicators (fragmentation, foraminiferal susceptibility, foraminiferal dissolution index, and abundance of benthic foraminifers) are compared in turn as follows:

1. Fragmentation shows a pattern that closely resembles the $\delta^{18} \mathrm{O}$ stack record (Martinson et al., 1987). Greater ranges of fragmentation values ( $20 \%$ to $30 \%$ ) occur during periods of maximum dissolution and can be attributed to noise and/or normal variations below the lysocline level. During intervals of dissolution minima values range $<10 \%$.

2. Variations in foraminiferal species susceptibility show some correspondence with fragmentation percentage: sharp troughs in the solution-susceptible species abundance (e.g., G. ruber and G. sacculifer; Figs. $2 \mathrm{~A}$ and $2 \mathrm{C}$, respectively) and sharp peaks in solution-resistant species (e.g., Globorotalia cultrata-Globorotalia tumida and Pulleniatina obliquiloculata: Figs. $2 \mathrm{G}$ and $2 \mathrm{H}$, respectively) generally match peaks in fragmentation percentage (Fig. 2E, Table 4). This pattern, however, does not apply to the entire record as peaks in solution-susceptible species sometimes correspond to high fragmentation values. Relative abundances of planktonic foraminifers are not only the product of dissolution, but of paleoclimate and paleoecological conditions in the upper water column.

3. The FDX curve is shown in Figure 4C. We would expect the FDX to follow a similar pattern to that depicted by fragmentation: higher values during dissolution intervals and lower values during preservation intervals. This pattern seems to apply below Termination II only; above it, values fluctuate between 0.65 and 0.86 , except for a high peak (1.0) at the base of dissolution Interval B3 (Fig. 4). Similarly to the foraminiferal susceptibility, the foraminiferal dissolution index reflects not only dissolution but is also influenced by paleoclimate and foraminiferal paleoecology.

4. The abundance of benthic foraminifers shows some correspondence with dissolution intervals (values higher than $1 \%$ ), but occasional anomalously high values are present during intervals of dissolution minima (e.g., during dissolution Interval B2). The abundance of benthic foraminifers reflects, therefore, not only dissolution but other factors such as paleoecological conditions of the seafloor.

From the above discussion it follows that planktonic foraminiferal fragmentation is the most sensitive dissolution indicator and will be further discussed below.

For Hole $832 \mathrm{~A}$, dissolution intervals are determined in the same fashion as for Hole $828 \mathrm{~A}$, using solution-susceptible vs. solution-resistant species, and where fragmentation percentage exceeds $15 \%$. This stratigraphy should be considered preliminary in the absence of the stable isotope record. The climatic/paleoecologic signal in this hole is highly distorted by sedimentological processes because anomalous percentages (e.g., high percentages of $G$. sacculifer coinciding with high percentage fragmentation, Fig. 3) were present. This also applies to the percentage of benthic foraminifers since they also do not coincide with test fragmentation. Test fragmentation in Hole 832A does not exceed $25 \%$ and hence is significantly lower than in Hole $828 \mathrm{~A}$.

\section{Relationship of Dissolution and Isotope Stages}

Dissolution Interval B1 as well as Interval B3C begin abruptly after preservation Intervals B2 and B4, respectively (Fig. 2E). Dissolution Interval B1 is Holocene in age ( 10 ka to present) and is preceded by dissolution minimum B2 that corresponds to the isotope Stage $2-1$ transition. The same pattern applies to the Stage 6-5
Table 3. Oxygen and carbon isotope data (per mil deviations from the PDB standard) for Globigerinoides sacculifer.

\begin{tabular}{|c|c|c|c|c|}
\hline \multirow{2}{*}{$\begin{array}{l}\text { Core, section, } \\
\text { interval }(\mathrm{cm})\end{array}$} & \multirow{2}{*}{$\begin{array}{l}\text { Depth } \\
\text { (mbsf) }\end{array}$} & \multirow{2}{*}{$\begin{array}{l}\text { Specimens } \\
(\mathrm{N})\end{array}$} & \multicolumn{2}{|c|}{ Planktonic foraminifers } \\
\hline & & & $\delta^{18} \mathrm{O}(\%)$ & $\delta^{13} \mathrm{C}(\%)$ \\
\hline \multicolumn{5}{|l|}{$134-828 \mathrm{~A}-$} \\
\hline $1 \mathrm{H}-1,44-46$ & 0.45 & 3 & -2.41 & 1.82 \\
\hline $1 \mathrm{H}-1,106-108$ & 1.06 & 7 & -2.02 & 0.14 \\
\hline $1 \mathrm{H}-3,82-83$ & 3.82 & 7 & -2.35 & 0.73 \\
\hline $2 \mathrm{H}-1,47-49$ & 4.87 & 7 & -1.97 & 0.02 \\
\hline $2 \mathrm{H}-2,79-81$ & 6.69 & 8 & -1.56 & 0.19 \\
\hline $2 \mathrm{H}-4,59-61$ & 9.49 & 8 & -0.81 & 0.09 \\
\hline $2 \mathrm{H}-5,59-61$ & 10.99 & 8 & -1.22 & 0.31 \\
\hline $3 \mathrm{H}-1,19-21$ & 14.09 & 8 & -0.86 & -0.03 \\
\hline $3 \mathrm{H}-3,99-101$ & 17.89 & 7 & -1.29 & 1.16 \\
\hline $3 \mathrm{H}-4,59-61$ & 18.99 & 7 & -1.06 & 0.85 \\
\hline $3 \mathrm{H}-6,19-21$ & 21.59 & 6 & -1.06 & 0.75 \\
\hline $4 \mathrm{H}-1,39-41$ & 23.79 & 7 & -0.99 & 1.13 \\
\hline $4 \mathrm{H}-2,139-141$ & 26.29 & 7 & -1.24 & 0.46 \\
\hline $4 \mathrm{H}-4,79-81$ & 28.69 & 7 & -1.33 & 0.36 \\
\hline $4 \mathrm{H}-5,79-81$ & 30.19 & 7 & -1.22 & 0.49 \\
\hline $5 \mathrm{H}-1,79-81$ & 33.69 & 7 & -1.66 & 1.13 \\
\hline $5 \mathrm{H}-2,56-58$ & 34.96 & 7 & -1.86 & 0.8 \\
\hline $5 \mathrm{H}-3,99-101$ & 35.39 & 7 & -1.72 & 0.52 \\
\hline $5 \mathrm{H}-4,119-121$ & 38.59 & 7 & -1.80 & 0.49 \\
\hline $5 \mathrm{H}-5,79-81$ & 39.69 & 7 & -1.76 & -0.05 \\
\hline $5 \mathrm{H}-6,59-61$ & 40.99 & 7 & -2.36 & 0.05 \\
\hline $5 \mathrm{H}-7,17-19$ & 42.07 & 7 & -2.18 & 0.02 \\
\hline $6 \mathrm{H}-1,100-102$ & 43.75 & 7 & -1.07 & -0.18 \\
\hline $6 \mathrm{H}-2,100-102$ & 45.25 & 8 & -0.92 & 0.13 \\
\hline $6 \mathrm{H}-3,100-102$ & 46.75 & 8 & -0.61 & -0.01 \\
\hline $6 \mathrm{H}-5,20-22$ & 48.90 & 8 & -0.97 & 0.23 \\
\hline $6 \mathrm{H}-6,100-102$ & 51.10 & 8 & -1.85 & 0.76 \\
\hline $6 \mathrm{H}-\mathrm{CC}, 20-22$ & 52.27 & 7 & -2.18 & -0.11 \\
\hline $7 \mathrm{H}-3,20-22$ & 55.65 & 8 & -1.49 & 0.99 \\
\hline $7 \mathrm{H}-4,100-102$ & 57.95 & 8 & -1.81 & 1.21 \\
\hline $7 \mathrm{H}-5,101-103$ & 59.45 & 8 & -1.45 & 0.58 \\
\hline
\end{tabular}

transition. Dissolution lags behind the ice-volume record by $\sim 8$ k.y., which is the difference between the widely accepted figure of $\sim 18 \mathrm{k} . \mathrm{y}$. for the LGM (Martinson et al., 1987) and $\sim 10$ k.y. for the last preservation spike (immediately below Sample 134-828A-2H-1, 29$31 \mathrm{~cm}$ ). A lag of a similar magnitude exists between the maximum ice-volume of Stage 6 ( 135 k.y., per Martinson et al., 1987) and its last preservation spike (125 k.y.). There is a good correspondence between the first peak in dissolution and minimum ice volume. This applies for interglacial Stages 1 and 5, but not necessarily Stage 7.

Furthermore, a pattern of variation of planktonic foraminifers can be seen during intervals of dissolution minima (i.e., that part of the record where percentage variations are reliable and not distorted by dissolution). Such is the case with $G$. sacculifer, which shows increasing values from Stage 6 (glacial maximum) to the Stage 6-5 transition, and from Stage 2 (the LGM) to the Stage 2-1 transition (Fig. 2C). This pattern of variations is opposite to that of the percentage abundance of Globigerina bulloides (Fig. 2F). Percentage variations do not exceed $15 \%$ and coincide with major variations in the stable isotope record.

Figures $4 \mathrm{~A}$ and $4 \mathrm{~B}$ were plotted bearing in mind the distortion of the ice-volume/paleotemperature record (the stable isotope record) and the climatic/paleoecologic signal (the foraminiferal record) caused by dissolution, and the possible reworking through turbidites and/or contourites. Unlike Figure 2, samples near any stratigraphic contact were excluded. The resulting reliability curve, with several species abundances, suggests the existence of short climatic/paleoecologic pulses, the actual meaning of which still needs to be defined or tested. This is the case with the relative drop in abundance of $G$. sacculifer at $\sim 7$ mbsf in Hole 828A that perhaps corresponds to the Younger Dryas event recently reported in the Sulu Sea (Linsley and Thunell, 1990; Kudrass et al., 1991) and the Gulf of Carpenteria (De Deckker et al., 1991). It is worth emphasizing here the strong resemblance between 

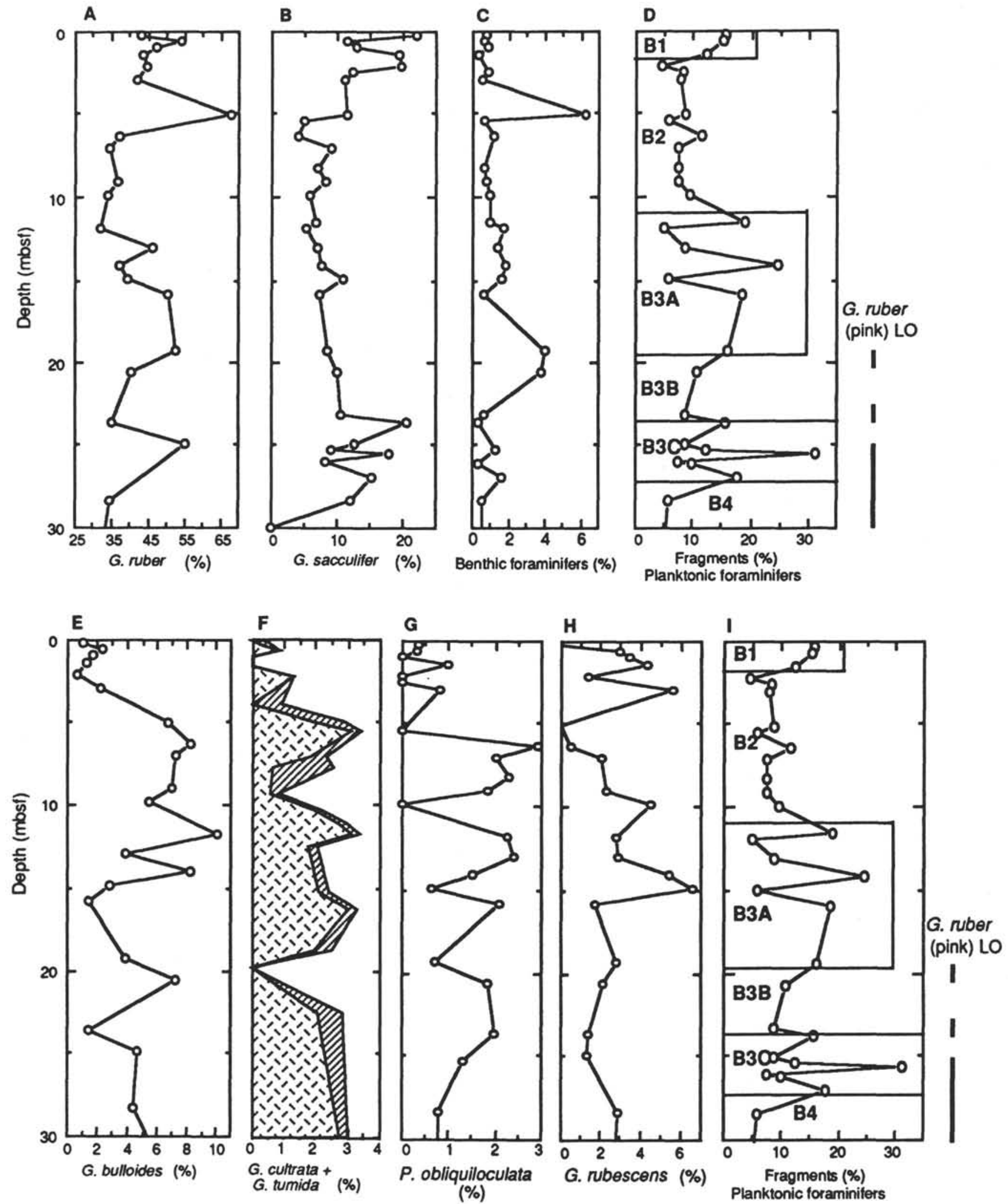

Figure 3. Hole 832A. Percentage variation of selected species of planktonic foraminifers (arranged according to their solution susceptibility) vs. the percentage of benthic foraminifers (C) and planktonic fragmentation (D, I). B1 to B5 refer to dissolution cycles. 
Table 4. Planktonic foraminifer fragmentation and three-point moving average for Hole 828A.

\begin{tabular}{|c|c|c|c|c|c|c|c|}
\hline \multirow[b]{2}{*}{$\begin{array}{l}\text { Core, section, } \\
\text { interval }(\mathrm{cm})\end{array}$} & \multirow[b]{2}{*}{$\begin{array}{l}\text { Depth } \\
\text { (mbsf) }\end{array}$} & \multicolumn{2}{|c|}{ Fragments } & \multirow[b]{2}{*}{$\begin{array}{l}\text { Core, section, } \\
\text { interval }(\mathrm{cm})\end{array}$} & \multirow[b]{2}{*}{$\begin{array}{l}\text { Depth } \\
\text { (mbsf) }\end{array}$} & \multicolumn{2}{|c|}{ Fragments } \\
\hline & & Percentage & $\begin{array}{c}\text { Three-point } \\
\text { moving } \\
\text { average }\end{array}$ & & & Percentage & $\begin{array}{c}\text { Three-point } \\
\text { moving } \\
\text { average }\end{array}$ \\
\hline $1 \mathrm{H}-1,44-46$ & 0.45 & 37.5 & - & $3 \mathrm{H}-3,119-121$ & 18.09 & 44.0 & 31.00 \\
\hline $1 \mathrm{H}-1,47-48$ & 0.48 & 27.7 & 38.10 & $3 \mathrm{H}-3,139-141$ & 18.29 & 37.0 & 37.30 \\
\hline $1 \mathrm{H}-1,106-108$ & 1.07 & 49.0 & 38.90 & $3 \mathrm{H}-4,19-21$ & 18.59 & 31.0 & 31.00 \\
\hline $1 \mathrm{H}-2,7-8$ & 1.57 & 39.9 & 40.10 & $3 \mathrm{H}-4,39-41$ & 18.79 & 25.0 & 27.70 \\
\hline $1 \mathrm{H}-2,57-58$ & 2.07 & 31.3 & 42.80 & $3 \mathrm{H}-4,59-61$ & 18.99 & 27.0 & 26.00 \\
\hline $1 \mathrm{H}-2,115-117$ & 2.65 & 57.4 & 39.80 & $3 \mathrm{H}-4,79-81$ & 19.19 & 26.0 & 27.90 \\
\hline $1 \mathrm{H}-3,20-21$ & 3.20 & 30.8 & 44.90 & $3 \mathrm{H}-4,99-101$ & 19.39 & 30.6 & 27.50 \\
\hline IH-3, 82-83 & 3.82 & 46.4 & 29.60 & $3 \mathrm{H}-4,119-121$ & 19.59 & 26.0 & 23.90 \\
\hline $2 \mathrm{H}-1,9-11$ & 4.49 & 11.8 & 21.30 & $3 \mathrm{H}-4,139-141$ & 19.79 & 15.0 & 21.60 \\
\hline $2 \mathrm{H}-1,29-31$ & 4.69 & 5.7 & 7.00 & $3 \mathrm{H}-5,19-21$ & 20.09 & 24.0 & 25.00 \\
\hline $2 \mathrm{H}-1,47-49$ & 4.87 & 3.4 & 5.20 & $3 \mathrm{H}-5,39-41$ & 20.29 & 36.0 & 25.00 \\
\hline $2 \mathrm{H}-1,69-71$ & 5.09 & 6.4 & 5.70 & $3 \mathrm{H}-5,59-91$ & 20.49 & 15.0 & 27.00 \\
\hline $2 \mathrm{H}-1.89-91$ & 5.29 & 7.4 & 6.80 & $3 \mathrm{H}-5,79-81$ & 20.69 & 30.0 & 23.30 \\
\hline $2 \mathrm{H}-1,109-111$ & 5.49 & 6.7 & 7.20 & $3 \mathrm{H}-5,99-101$ & 20.89 & 25.0 & 27.00 \\
\hline $2 \mathrm{H}-1,129-131$ & 5.69 & 7.6 & 6.40 & $3 \mathrm{H}-5,119-121$ & 21.09 & 26.0 & 27.00 \\
\hline $2 \mathrm{H}-2,1-3$ & 5.91 & 4.9 & 6.50 & $3 \mathrm{H}-5,139-141$ & 21.29 & 27.0 & 29.00 \\
\hline $2 \mathrm{H}-2,19-21$ & 6.09 & 6.9 & 5.60 & $3 \mathrm{H}-6,19-21$ & 21.59 & 39.0 & 28.30 \\
\hline $2 \mathrm{H}-2,39-41$ & 6.29 & 5.0 & 6.50 & $3 \mathrm{H}-6,39-41$ & 21.79 & 21.0 & 22.10 \\
\hline $2 \mathrm{H}-2,58-6 \mathrm{I}$ & 6.48 & 7.5 & 5,70 & $3 \mathrm{H}-6,59-61$ & 21.99 & 25.0 & 24.10 \\
\hline $2 \mathrm{H}-2,79-81$ & 6.69 & 4.5 & 6.30 & $3 \mathrm{H}-6,99-101$ & 22.39 & 27.0 & 24.10 \\
\hline $2 \mathrm{H}-2,99-101$ & 6.89 & 5.8 & 5.50 & $3 \mathrm{H}-6,119-121$ & 22.59 & 25.0 & 29.30 \\
\hline $2 \mathrm{H}-2,120-122$ & 7.10 & 5.1 & 6.90 & $3 \mathrm{H}-6,139-141$ & 22.79 & 36.0 & 34.20 \\
\hline $2 \mathrm{H}-2,139-141$ & 7.29 & 8.9 & 8.00 & $3 \mathrm{H}-7,19-21$ & 23.09 & 41.5 & 32.50 \\
\hline $2 \mathrm{H}-3,9-11$ & 7.49 & 10.0 & 8.90 & $3 \mathrm{H}-7,39-41$ & 23.29 & 20.0 & 24.80 \\
\hline $2 \mathrm{H}-3,29-3 \mathrm{I}$ & 7.69 & 7.8 & 11.80 & $3 \mathrm{H}-7,58-60$ & 23.48 & 13.0 & 23.00 \\
\hline $2 \mathrm{H}-3,48-50$ & 7.88 & 17.6 & 10.70 & $4 \mathrm{H}-1,23-24$ & 23.63 & 36.0 & 22.00 \\
\hline $2 \mathrm{H}-3,69-71$ & 8.09 & 6.7 & 12.00 & $4 \mathrm{H}-1,39-41$ & 23.79 & 17.0 & 27.70 \\
\hline $2 \mathrm{H}-3,89-91$ & 8.29 & 11.6 & 8.90 & $4 \mathrm{H}-1,59-61$ & 23.99 & 30.0 & 23.00 \\
\hline $2 \mathrm{H}-3,109-111$ & 8.49 & 8.4 & 9.10 & $4 \mathrm{H}-1,79-81$ & 24.19 & 22.0 & 31.70 \\
\hline $2 \mathrm{H}-3,129-131$ & 8.69 & 7.4 & 9.80 & $4 \mathrm{H}-1,99-101$ & 24.39 & 43.0 & 34.70 \\
\hline $2 \mathrm{H}-3,148-150$ & 8.88 & 13.5 & 11.60 & $4 \mathrm{H}-1,119-121$ & 24.59 & 39.0 & 33.00 \\
\hline $2 \mathrm{H}-4,19-21$ & 9.09 & 14.0 & 13.30 & $4 \mathrm{H}-1,139-141$ & 24.79 & 17.0 & 25.40 \\
\hline $2 \mathrm{H}-4,39-41$ & 9.29 & 12.5 & 13.10 & $4 \mathrm{H}-2,19-21$ & 25.09 & 20.2 & 17.70 \\
\hline $2 \mathrm{H}-4,59-61$ & 9.49 & 12.9 & 12.70 & $4 \mathrm{H}-2,39-41$ & 25.29 & 16.0 & 21.70 \\
\hline $2 \mathrm{H}-4,79-81$ & 9.69 & 12.8 & 12.80 & $4 \mathrm{H}-2,59-61$ & 25.49 & 29.0 & 25.30 \\
\hline $2 \mathrm{H}-4,99-101$ & 9.89 & 12.8 & 13.00 & $4 \mathrm{H}-2,79-81$ & 25.69 & 31.0 & 33.67 \\
\hline $2 \mathrm{H}-4,119-121$ & 10.09 & 13.4 & 14.40 & $4 \mathrm{H}-2,99-101$ & 25.89 & 41.0 & 31.24 \\
\hline $2 \mathrm{H}-5,2-4$ & 10.42 & 16.9 & 15.70 & $4 \mathrm{H}-2,119-121$ & 26.09 & 21.7 & 27.58 \\
\hline $2 \mathrm{H}-5,20-22$ & 10.60 & 16.8 & 16.50 & $4 \mathrm{H}-2,139-141$ & 26.29 & 20.0 & 19.91 \\
\hline $2 \mathrm{H}-5,40-42$ & 10.80 & 15.9 & 16.40 & $4 \mathrm{H}-3,19-21$ & 26.59 & 18.0 & 15.67 \\
\hline $2 \mathrm{H}-5,59-61$ & 10.99 & 16.5 & 12.20 & $4 \mathrm{H}-3,39-41$ & 26.79 & 9.0 & 18.01 \\
\hline $2 \mathrm{H}-5,79-81$ & 11.19 & 4.1 & 14.30 & $4 \mathrm{H}-3,59-61$ & 26.99 & 27.0 & 15.01 \\
\hline $2 \mathrm{H}-5,100-102$ & 11.40 & 22.4 & 16.70 & $4 \mathrm{H}-3,79-81$ & 27.19 & 9.0 & 16.01 \\
\hline $2 \mathrm{H}-5,120-122$ & 11.60 & 23.6 & 21.20 & $4 \mathrm{H}-3,99-101$ & 27.39 & 12.0 & 11.67 \\
\hline $2 \mathrm{H}-5,140-142$ & 11.80 & 17.7 & 20.40 & $4 \mathrm{H}-3,119-121$ & 27.59 & 14.0 & 14.00 \\
\hline $2 \mathrm{H}-6,12-14$ & 12.02 & 19.8 & 18.60 & $4 \mathrm{H}-3,139-141$ & 27.79 & 16.0 & 18.67 \\
\hline $2 \mathrm{H}-6,30-32$ & 12.20 & 18.3 & 23.30 & $4 \mathrm{H}-4,19-21$ & 28.09 & 26.0 & 18.67 \\
\hline $2 \mathrm{H}-6,48-50$ & 12.38 & 31.7 & 23.20 & $4 \mathrm{H}-4,39-41$ & 28.29 & 14.0 & 19.00 \\
\hline $2 \mathrm{H}-6,69-71$ & 12.59 & 19.5 & 22.80 & $4 \mathrm{H}-4,59-61$ & 28.49 & 17.0 & 24.00 \\
\hline $2 \mathrm{H}-6,89-91$ & 12.79 & 17.2 & 17.80 & $4 \mathrm{H}-4,79-81$ & 28.69 & 41.0 & 22.33 \\
\hline $2 \mathrm{H}-6,110-112$ & 13.00 & 16.7 & 20.10 & $4 \mathrm{H}-4,99-101$ & 28.89 & 9.0 & 25.02 \\
\hline $2 \mathrm{H}-6,130-132$ & 13.20 & 26.3 & 21.70 & $4 \mathrm{H}-4,119-121$ & 29.09 & 25.1 & 16.69 \\
\hline $2 \mathrm{H}-7,2-4$ & 13.42 & 22.2 & 25.70 & $4 \mathrm{H}-4,139-141$ & 29.29 & 16.0 & 20.35 \\
\hline $2 \mathrm{H}-7,22-24$ & 13.62 & 28.7 & 27.00 & $4 \mathrm{H}-5,19-21$ & 29.59 & 20.0 & 19.67 \\
\hline $2 \mathrm{H}-7,40-42$ & 13.80 & 30.2 & 26.10 & $4 \mathrm{H}-5,39-41$ & 29.79 & 23.0 & 26.22 \\
\hline $3 \mathrm{H}-1,19-21$ & 14.09 & 19.3 & 22.80 & $4 \mathrm{H}-5,59-61$ & 29.99 & 35.7 & 29.22 \\
\hline $3 \mathrm{H}-1,39-41$ & 14.29 & 19.0 & 19.40 & $4 \mathrm{H}-5,79-81$ & 30.19 & 29.0 & 36.56 \\
\hline $3 \mathrm{H}-1,59-61$ & 14.49 & 20.0 & 19.00 & $4 \mathrm{H}-5,99-101$ & 30.39 & 45.0 & 33.33 \\
\hline $3 \mathrm{H}-1,79-81$ & 14.69 & 18.0 & 21.30 & $4 \mathrm{H}-5,119-121$ & 30.59 & 26.0 & 32.00 \\
\hline $3 \mathrm{H}-1,99-101$ & 14.89 & 26.0 & 32.70 & $4 \mathrm{H}-5,139-141$ & 30.79 & 25.0 & 32.75 \\
\hline $3 \mathrm{H}-1,119-121$ & 15.09 & 23.0 & 27.30 & $4 \mathrm{H}-6,19-21$ & 31.09 & 47.3 & 37.08 \\
\hline $3 \mathrm{H}-1,139-141$ & 15.29 & 33.0 & 31.00 & $4 \mathrm{H}-6,39-41$ & 31.29 & 39.0 & 39.75 \\
\hline $3 \mathrm{H}-2,19-21$ & 15.59 & 37.0 & 33.00 & $4 \mathrm{H}-6,59-61$ & 31.49 & 33.0 & 41.00 \\
\hline $3 \mathrm{H}-2,39-41$ & 15.79 & 29.0 & 31.70 & $4 \mathrm{H}-6,79-81$ & 31.69 & 51.0 & 47.67 \\
\hline $3 \mathrm{H}-2,59-61$ & 15.99 & 29.0 & 27.00 & $4 \mathrm{H}-6,99-101$ & 31.89 & 59.0 & 52.04 \\
\hline $3 \mathrm{H}-2,79-81$ & 16.19 & 23.0 & 25.00 & $4 \mathrm{H}-6,119-121$ & 32.09 & 46.1 & 46.37 \\
\hline $3 \mathrm{H}-2,99-101$ & 16.39 & 25.0 & 24.00 & $4 \mathrm{H}-6,139-141$ & 32.29 & 34.0 & 40.04 \\
\hline $3 \mathrm{H}-2,119-121$ & 16.59 & 26.0 & 28.00 & $4 \mathrm{H}-7,19-21$ & 32.59 & 40.0 & 45.00 \\
\hline $3 \mathrm{H}-2,139-141$ & 16.79 & 35.0 & 28.00 & $4 \mathrm{H}-7,39-41$ & 32.79 & 61.0 & 46.74 \\
\hline $3 \mathrm{H}-3,19-21$ & 17.09 & 23.0 & 33.70 & $4 \mathrm{H}-\mathrm{CC}, 19-21$ & 33.02 & 39.2 & 42.07 \\
\hline $3 \mathrm{H}-3,39-41$ & 17.29 & 43.0 & 30.00 & $5 \mathrm{H}-1,19-21$ & 33.09 & 26.0 & 32.74 \\
\hline $3 \mathrm{H}-3,59-61$ & 17.49 & 24.0 & 29.30 & $5 \mathrm{H}-1,39-41$ & 33.29 & 33.0 & 49.67 \\
\hline $3 \mathrm{H}-3,79-81$ & 17.69 & 21.0 & 19.00 & $5 \mathrm{H}-1,62-64$ & 33.52 & 57.0 & 45.00 \\
\hline $3 \mathrm{H}-3,99-101$ & 17.89 & 12.0 & 25.70 & $5 \mathrm{H}-1,79-81$ & 33.69 & 45.0 & 42.00 \\
\hline
\end{tabular}


Table 4 (continued).

\begin{tabular}{|c|c|c|c|c|c|c|c|}
\hline \multirow[b]{2}{*}{$\begin{array}{l}\text { Core, section, } \\
\text { interval }(\mathrm{cm})\end{array}$} & \multirow[b]{2}{*}{$\begin{array}{l}\text { Depth } \\
\text { (mbsf) }\end{array}$} & \multicolumn{2}{|c|}{ Fragments } & \multirow[b]{2}{*}{$\begin{array}{l}\text { Core, section, } \\
\text { interval }(\mathrm{cm})\end{array}$} & \multirow[b]{2}{*}{$\begin{array}{l}\text { Depth } \\
\text { (mbsf) }\end{array}$} & \multicolumn{2}{|c|}{ Fragments } \\
\hline & & Percentage & $\begin{array}{c}\text { Three-point } \\
\text { moving } \\
\text { average }\end{array}$ & & & Percentage & $\begin{array}{c}\text { Three-point } \\
\text { moving } \\
\text { average }\end{array}$ \\
\hline $5 \mathrm{H}-1,99-101$ & 33.89 & 24.0 & 34.67 & $5 \mathrm{H}-6,99-101$ & 41.39 & 55.0 & 48.00 \\
\hline $5 \mathrm{H}-1,119-121$ & 34.09 & 35.0 & 33.67 & $5 \mathrm{H}-6,119-121$ & 41.59 & 21.0 & 38.30 \\
\hline $5 \mathrm{H}-1,139-141$ & 34.29 & 42.0 & 43.33 & SH-6, 139-141 & 41.79 & 39.0 & 24.10 \\
\hline $5 \mathrm{H}-2,19-21$ & 34.59 & 53.0 & 47.00 & $5 \mathrm{H}-7,17-19$ & 42.07 & 12.3 & 18.77 \\
\hline $5 \mathrm{H}-2,39-41$ & 34.79 & 46.0 & 48.33 & $5 \mathrm{H}-7,39-41$ & 42.29 & 5.0 & 8.43 \\
\hline $5 \mathrm{H}-2,56-58$ & 34.96 & 46.0 & 43.73 & $5 \mathrm{H}-7,59-61$ & 42.49 & 8.0 & 8.33 \\
\hline $5 \mathrm{H}-2,79-81$ & 35.19 & 39.2 & 40.73 & $5 \mathrm{H}-\mathrm{CC}, 19-21$ & 42.76 & 12.0 & 9.40 \\
\hline $5 \mathrm{H}-2,99-101$ & 35.39 & 37.0 & 50.39 & $6 \mathrm{H}-1,20-22$ & 42.95 & 8.1 & 11.67 \\
\hline $5 \mathrm{H}-2,119-121$ & 35.59 & 75.0 & 53.00 & $6 \mathrm{H}-1,100-102$ & 43.75 & 14.9 & 12.25 \\
\hline $5 \mathrm{H}-2,139-141$ & 35.79 & 47.0 & 55.10 & $6 \mathrm{H}-2,20-22$ & 44.45 & 13.7 & 16.11 \\
\hline $5 \mathrm{H}-3,19-21$ & 36.09 & 43.3 & 46.10 & $6 \mathrm{H}-2,100-102$ & 45.25 & 19.7 & 14.81 \\
\hline $5 \mathrm{H}-3,39-41$ & 36.29 & 48.0 & 49.43 & $6 \mathrm{H}-3,20-22$ & 45.95 & 11.0 & 13.99 \\
\hline $5 \mathrm{H}-3,59-61$ & 36.49 & 57.0 & 49.67 & $6 \mathrm{H}-3,100-102$ & 46.75 & 11.3 & 10.09 \\
\hline $5 \mathrm{H}-3,79-81$ & 36.69 & 47.0 & 49.67 & $6 \mathrm{H}-4,20-22$ & 47.40 & 8.0 & 13.67 \\
\hline $5 \mathrm{H}-3,99-101$ & 36.89 & 45.0 & 47.67 & $6 \mathrm{H}-4,100-102$ & 48.20 & 21.7 & 13.79 \\
\hline $5 \mathrm{H}-3,119-121$ & 37.09 & 51.0 & 42.33 & $6 \mathrm{H}-5,20-22$ & 48.90 & 11.6 & 16.20 \\
\hline $5 \mathrm{H}-3,139-141$ & 37.29 & 31.0 & 38.00 & $6 \mathrm{H}-5,100-102$ & 49.70 & 15.2 & 22.90 \\
\hline $5 \mathrm{H}-4,19-21$ & 37.59 & 32.0 & 31.00 & $6 \mathrm{H}-6,17-19$ & 50.10 & 41.8 & 30.56 \\
\hline $5 \mathrm{H}-4,39-41$ & 37.79 & 30.0 & 32.33 & $6 \mathrm{H}-6,100-102$ & 51.10 & 34.6 & 39.18 \\
\hline $5 \mathrm{H}-4,60-62$ & 38.00 & 36.0 & 32.00 & $6 \mathrm{H}-7,20-22$ & 51.80 & 41.1 & 29.89 \\
\hline $5 \mathrm{H}-4,79-81$ & 38.19 & 31.0 & 46.67 & $6 \mathrm{H}-\mathrm{CC}, 20-22$ & 52.27 & 14.0 & 21.58 \\
\hline $5 \mathrm{H}-4,99-101$ & 38.39 & 74.0 & 48.00 & $7 \mathrm{H}-1,21-23$ & 52.65 & 9.7 & 12.55 \\
\hline $5 \mathrm{H}-4,119-121$ & 38.59 & 39.0 & 51.33 & $7 \mathrm{H}-1,101-103$ & 53.45 & 14.0 & 11.61 \\
\hline $5 \mathrm{H}-4,139-141$ & 38.79 & 41.0 & 40.67 & $7 \mathrm{H}-2,20-22$ & 54.15 & 11.1 & 13.63 \\
\hline $5 \mathrm{H}-5,19-21$ & 39.09 & 42.0 & 38.00 & $7 \mathrm{H}-2,10 \mathrm{I}-103$ & 54.95 & 15.7 & 16.68 \\
\hline $5 \mathrm{H}-5,39-41$ & 39.29 & 31.0 & 41.67 & $7 \mathrm{H}-3,20-22$ & 55.65 & 23.2 & 21.91 \\
\hline $5 \mathrm{H}-5,59-61$ & 39.49 & 52.0 & 40.33 & $7 \mathrm{H}-3,100-102$ & 56.45 & 26.8 & 21.80 \\
\hline $5 \mathrm{H}-5,79-81$ & 39.69 & 38.0 & 45.33 & $7 \mathrm{H}-4,20-22$ & 57.15 & 15.5 & 25.19 \\
\hline $5 \mathrm{H}-5,99-101$ & 39.89 & 46.0 & 50.65 & $7 \mathrm{H}-4,100-102$ & 57.95 & 33.3 & 18.45 \\
\hline $5 \mathrm{H}-5,119-121$ & 40.09 & 67.9 & 61.32 & $7 \mathrm{H}-5,20-22$ & 58.65 & 6.5 & 15.52 \\
\hline $5 \mathrm{H}-5,139-141$ & 40.29 & 70.0 & 77.65 & $7 \mathrm{H}-5,101-103$ & 59.45 & 6.7 & 8.04 \\
\hline $5 \mathrm{H}-6,19-21$ & 40.59 & 95.0 & 83.00 & $7 \mathrm{H}-6,20-22$ & 60.15 & 10.9 & 8.00 \\
\hline $5 \mathrm{H}-6,39-41$ & 40.79 & 84.0 & 75.97 & $7 \mathrm{H}-6,111-113$ & 60.95 & 6.4 & 8.08 \\
\hline $5 \mathrm{H}-6,59-61$ & 40.99 & 48.9 & 66.97 & $7 \mathrm{H}-7,16-18$ & 61.62 & 6.9 & - \\
\hline $5 H-6,79-81$ & 41.19 & 68.0 & 57.3 & & & & \\
\hline
\end{tabular}

the fragmentation curve and both the $\mathrm{CO}_{2}$ Antarctic record (Barnola et al., 1987) and the $\delta^{18} \mathrm{O}$ record on Ontong Java Plateau (Shackleton and Opdyke, 1976).

The low variation in abundance of some subtropical to transitional (cold water) species, such as $G$. bulloides, Globorotalia inflata, and Globorotalia truncatulinoides between glacial-interglacial cycles, supports the paleotemperature estimations of Anderson et al. (1989). These authors found that, for the northern part of the Coral Sea, sea-surface temperatures remained constant or changed very slightly between the LGM and the present, viz. $29^{\circ} \mathrm{C}$ in summer and $27^{\circ} \mathrm{C}$ in winter, as depicted at Hole RC10-131 located northwest of ODP Holes 828A and 832A (Anderson et al., 1989).

\section{Sedimentation Rates}

Figure 5A depicts the inferred average sedimentation rate curve for the upper $62 \mathrm{mbsf}$ interval, drawn on the basis of $\mathrm{AMS}^{14} \mathrm{C}$ ages, stable isotope data, and the last occurrence of $G$. ruber (pink variety). Average sedimentation rates increased progressively and dramatically ( $\sim 10$ to $\sim 50 \mathrm{~cm} / \mathrm{k} . \mathrm{y}$.) as more terrigenous material became available. The significance of this change is discussed below. An additional test to determine the possible influence of turbidites on the fragmentation record was performed by plotting the number of stratigraphic contacts against the mean percentage of fragments in each dissolution-preservation interval (Fig. 6). No correlation appears from this figure, suggesting that turbidites have no significant effect on fragmentation. The number of geologic contacts was obtained from the sedimentological logs (Collot, Greene, Stokking, et al., 1992) and from core photographs. It is certain that with the aid of additional techniques (e.g., X-ray radiographs) hidden contacts will appear. It is worth emphasizing here that the highest frequency of stratigraphic contacts per meter, and hence the interval of maximum episodic sedimentation of the record, occurs towards the top of Hole $828 \mathrm{~A}$, showing a maximum around $10 \mathrm{mbsf}$ (i.e., the LGM).

Sedimentation rates for Hole $832 \mathrm{~A}$ are slightly lower than those for Hole $828 \mathrm{~A}$, based on the only control point available, the last occurrence of $G$. ruber (pink variety) at $\sim 28 \mathrm{mbsf}$ (Fig. 3). Planktonic foraminifers were counted, where possible, at intermittent intervals below 30 mbsf (not illustrated). However, because of the increasing abundance of volcanic ash, no pattern could be determined.

\section{DISCUSSION}

\section{Paleoceanography}

Dissolution cycles found in Holes 828A and 832A closely resemble the established pattern for the western equatorial Pacific; the two sites are in the southernmost limit of this dissolution regime. Farrell and Prell (1989) showed the modern lysocline to be at approximately $4 \mathrm{~km}$ (based on percentage of $\mathrm{CaCO}_{3}$ in core tops) for the central equatorial Pacific, whereas Parker and Berger (1971) suggested that it is around $3.4 \mathrm{~km}$ for the western equatorial Pacific. More recently Wu et al. (1991) proposed that the lysocline fluctuated between 3.6 $\mathrm{km}$ during deglacial transitions and $2.6 \mathrm{~km}$ during stages of ice growth in the western equatorial Pacific.

Figure 7 shows the modern foraminiferal lysocline profile for the area between $160^{\circ}$ and $180^{\circ} \mathrm{E}$, and $10^{\circ}$ and $30^{\circ} \mathrm{S}$ (Table 5). Foraminiferal fragmentation from 23 core-top samples were plotted against water depth. Fragmentation above $3.1 \mathrm{~km}$ varies between $5 \%$ and 

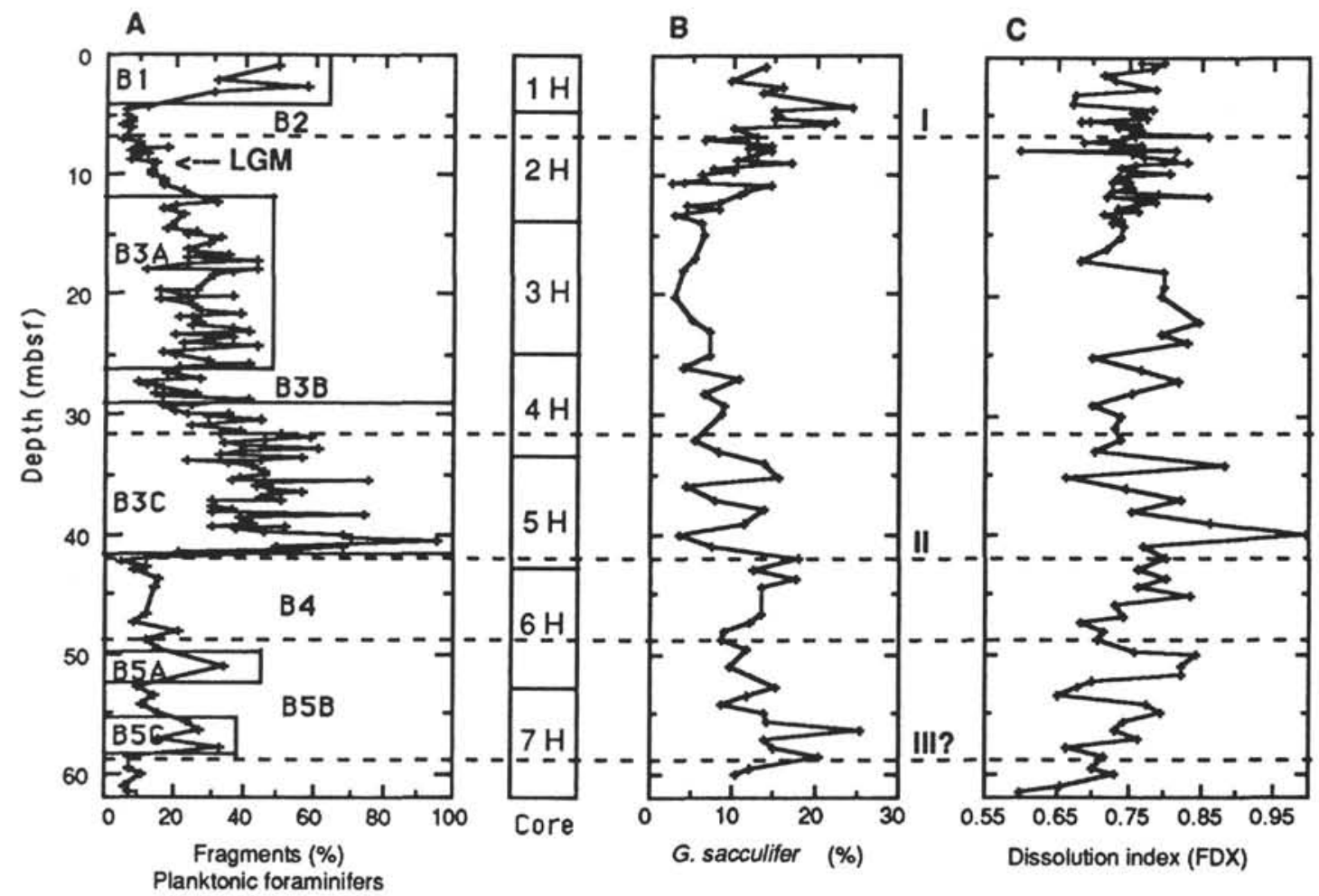

Figure 4. Hole 828A. (A) Percentage of fragments and (B) G. sacculifer remaining after the exclusion of those samples close to stratigraphic contacts ("reliability curve"), and (C) the foraminiferal dissolution index FDX $=\sum\left(P_{i} R_{i}\right) / r_{i}$.

$14 \%$, with 2 anomalous $20 \%$ values. Fragmentation below $3.1 \mathrm{~km}$ increases dramatically from $22 \%$ reaching a maximum of $60 \%$. One anomalous $12 \%$ value occurs below $4 \mathrm{~km}$. The lysocline level $(3.1 \mathrm{~km})$ marks the water depth where dissolution starts to increase; below $4.25 \mathrm{~km}$ some planktonic foraminifers are completely dissolved. The anomalous fragmentation of samples around $2 \mathrm{~km}$ possibly results from the presence of a deep oxygen-minimum zone at this level (Wyrtki, 1961), higher $\mathrm{CO}_{2}$ content, and corrosive water. The anomalous sample at about $4 \mathrm{~km}$ possibly results from the proximity of the carbonate compensation depth: here dissolution is so intense that fragments of planktonic foraminifers are greatly reduced in size and consequently not retained in the size fraction examined (i.e., $>150$ $\mu \mathrm{m})$. Le and Shackleton (1992) show that the carbonate saturation index $\left(\Delta \mathrm{CO}_{3}=\right)$ diminishes below the level where fragmentation increases sharply, and they replot Berger et al.'s (1982) modern lysocline data for the Ontong Java Plateau (their Fig. 5). The carbonate saturation index indicates the degree of calcite saturation in seawater and represents the difference between the in-situ $\left(\mathrm{CO}_{3}=\right)$ of seawater and the saturation $\left(\mathrm{CO}_{3}=\right)$ of calcite (Broecker and Peng, 1982). Le and Shackleton (1992) found very similar results to those shown here (including the anomalous sample at about $4 \mathrm{~km}$ ), with the lysocline level at $3 \mathrm{~km}$ depth. Figure 7 and the work of Le and Shackleton (1992) show that fragmentation is a very sensitive indicator of the lysocline position in the water column. As indicated above, the limits of dissolution intervals in Figure 2 were defined at the $20 \%$ fragmentation value, which is somewhat higher than fragmentation percentage above the lysocline in the region (Fig. 7). It follows that the lysocline level was shallower during dissolution intervals, and deeper during preservation intervals. Thus, we can express variations in fragmentation percentage in terms of equivalent water depths, and then infer the lysocline level depth through time. Figure $8 \mathrm{~B}$ was drawn by comparing average fragmentation percentage from each dissolution interval with fragmentation percentages from the present day lysocline (Fig. 7). Error bars are indicated by shaded areas. Equivalent water depths are referenced to the present seafloor depth $(3086 \mathrm{~m})$ and indicate the relative position of the lysocline level (upper scale on Fig. 8B). Values above the modern lysocline show high error bars; consequently, it is impossible to assess the past lysocline level position (i.e., during intervals of low dissolution). The lower scale in Figure 8B shows the equivalent lysocline variations in the past. Deeper than $3086 \mathrm{~m}$, lysocline levels during intervals of dissolution minima (B2, B3B, B4, and $\mathrm{B} 5 \mathrm{~B})$ are indicated only as relative positions, whereas shallower lysocline levels during dissolution maxima (B1, B3A, B3B, B5A, and $\mathrm{B} 5 \mathrm{C}$ ) range from $\sim 2550$ to $3000 \mathrm{~m}$. The average fragmentation value of dissolution Interval B1, when compared with the present-day lysocline profile, suggests that the lysocline level west of Vanuatu is shallower than $3086 \mathrm{~m}$. This indicates that the lysocline profile west of Vanuatu is of the near-continent type, but was of an open ocean type before Termination II (cf. Berger, 1970). The change of the lysocline profile through time may have influenced dissolution intensity and the fragmentation percentage, therefore biasing the position of the inferred lysocline in the past. The wide range of variation of fragmentation percentages during dissolution intervals ("noise" in Fig. 2E) appears to be the normal situation for samples below the lysocline level (see Fig. 7). Differences in sedimentation rate, sediment disturbance (reworking and mixing), and temporal variations in the $\Delta \mathrm{CO}_{3}=$ profile could explain these fluctuations. As indicated above, the fragmentation curve shows an intriguing similarity with the $\delta^{18} \mathrm{O}$ stack record (Martinson et al., 1987). This similarity is closer (by eliminating some noise) when comparing the $\delta^{18} \mathrm{O}$ record with a 3-point moving average fragmentation curve (Fig. 8A).

Parker and Berger (1971) showed how for the eastern equatorial Pacific upwelling high productivity and consequently high export of organic matter to deep waters enhances dissolution and raises the lysocline $\left(\mathrm{CO}_{2}\right.$ in pore waters is produced by oxidation of organic matter). At present, there are no indications of upwelling in the Vanuatu region. However, the Trade Winds may force some offshore movement of water along the western side of Espiritu Santo Island, 


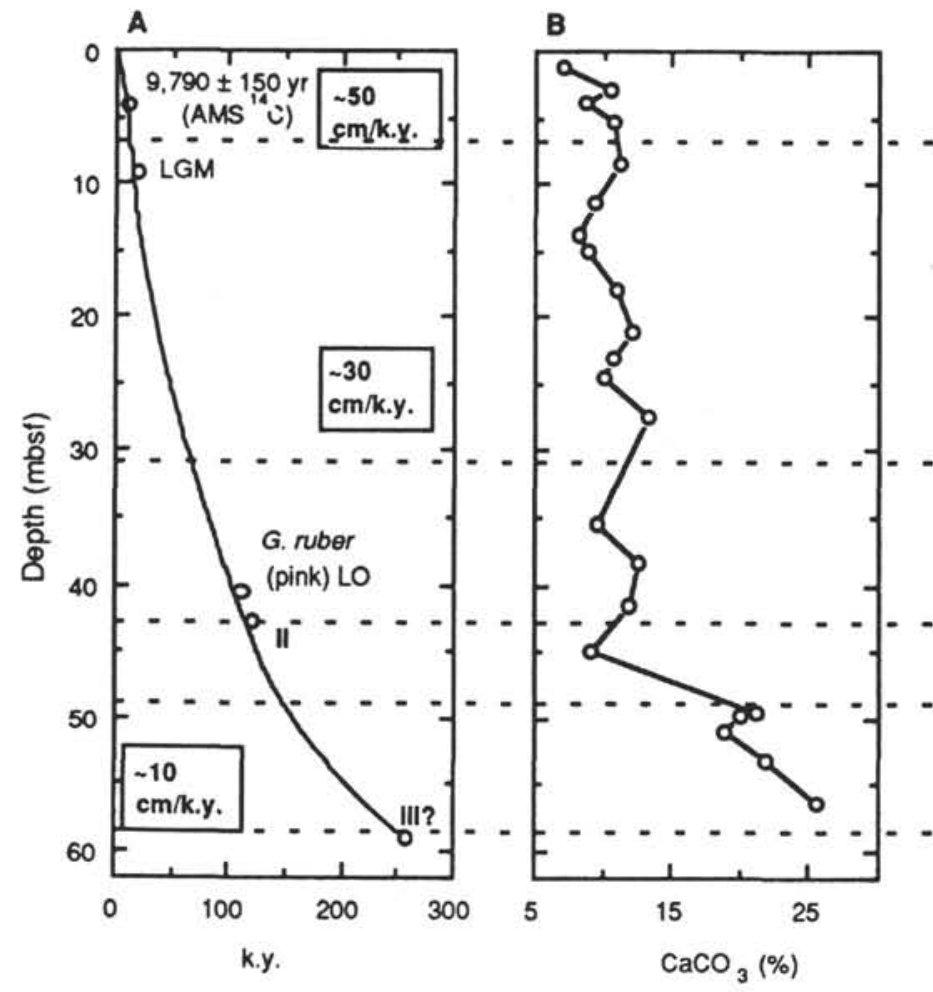

Figure 5. Hole $828 \mathrm{~A}$. (A) Average sedimentation rate curve and (B) percentage of $\mathrm{CaCO}_{3}$; (C) the fragmentation
average) is included for comparison. Isotopic Stages 1 to 7 , as well as dissolution Cycles $\mathrm{B} 1$ to $\mathrm{B} 5$ are indicated.

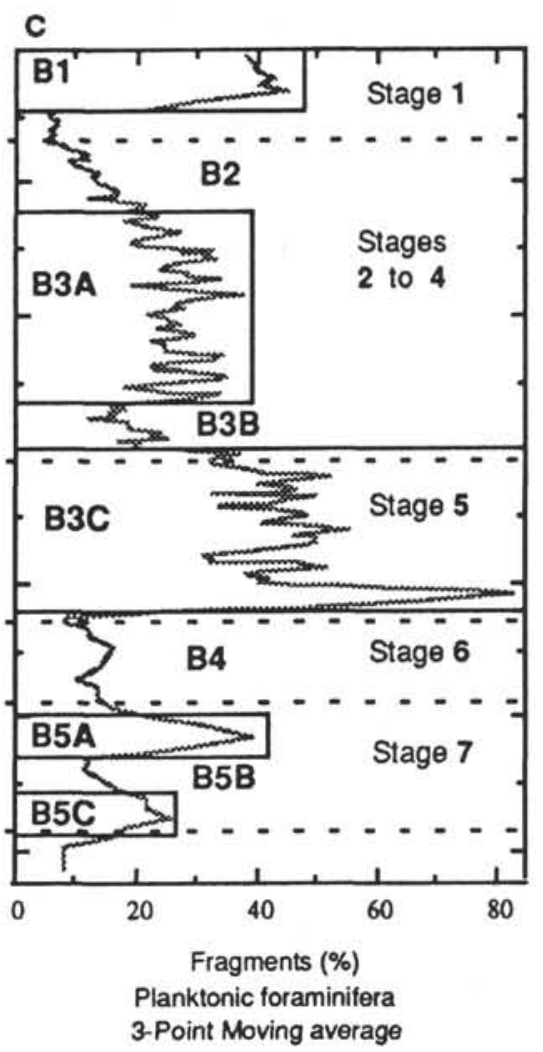

thus triggering some upwelling. If some productivity blooms did occur, these were greatly diluted by terrigenous material, as shown by the low contents of total organic carbon (TOC up to $0.5 \%$, see Collot, Greene, Stokking, et al., 1992), although TOC may come from wood fragments rather than plankton. As mentioned above, mid-water flows (and turbidites) are an ever-present feature that, together with the common occurrence of woody material, account for the high supply of terrigenous sediments, which may prevent plankton blooms from occurring in the area.

When comparing ODP Hole 828A with Hole V28-238 (collected at $3120 \mathrm{~m}$ by Thompson, 1976), a pattern of slightly less fragmentation and small calcium carbonate fluctuations due to dilution by terrigenous material is found. Carbonate cyclicity is the result of an interplay of (1) changes in productivity and rates of sediment fluxes, keeping dissolution rates of carbonate at constant level; (2) flux variations in the ratios of calcareous particles to siliceous particles; (3) changes in dilution by nonbiogenic material such as terrigenous and volcanic particles; and (4) fluctuations in carbonate dissolution (Wu et al., 1991). Quaternary records of carbonate dissolution cycles have been referred to as "periodites" (Einsele, 1982b) because they are of allocyclic origin (i.e., the above-mentioned parameters). In Vanuatu, this periodite pattern has been partially obliterated by terrigenous input. This pattern is shown in Figure 5B (data from Collot, Greene, Stokking, et al., 1992). The sedimentary parameters, bioturbation, and sedimentation rate of the background sediments of turbidites may remain more or less unaffected (Einsele, 1982a), if we assume a simple situation in which we have constant carbonate supply, nonbiogenic supply increasing upwards, and dissolution varying cyclically. Then, from the combination of these three parameters we can expect to see the upward decrease of $\mathrm{CaCO}_{3}$ with lower values caused by dissolution (cf. Einsele and Ricken, 1991). In Hole 828A this pattern is not evident except, perhaps, for dissolution Interval B 1
(Fig. 5B). Carbonate supply and/or nonbiogenic supply must vary accordingly to produce the observed $\mathrm{CaCO}_{3}$ pattern. Figure 9 shows a semi-quantitative way to explore the influence of the nonbiogenic supply (terrigenous dilution) and dissolution on the $\mathrm{CaCO}_{3}$ record (Dean et al., 1981; Diester-Haass, 1991). $\mathrm{CaCO}_{3}$ content has been plotted vs. carbonate dissolution (benthic/[benthic + planktonic foraminifers]) for Hole 828A. It appears that dissolution and dilution increase from Cores $139-828 \mathrm{~A}-7 \mathrm{H}$ to $-1 \mathrm{H}$. From this figure, however, it is uncertain whether or not carbonate input has varied. Cores $6 \mathrm{H}$ and $7 \mathrm{H}$ show the lowest degree of dissolution, but increasing dilution. If carbonate supply increased from Core $7 \mathrm{H}$ to $1 \mathrm{H}$, then terrigenous input would have favored rather than prevented the bloom of calcareous plankton (foraminifers and nannofossils) in the area. Core $1 \mathrm{H}$ shows a maximum in dissolution and dilution whereas Cores $2 \mathrm{H}$ to $5 \mathrm{H}$ show intermediate values. Berger (1968) and Parker and Berger (1971) based their lysocline models on the gradient of the FDX. FDX values are affected by the interference of the solution ranking with the latitudinal and depth rankings (Berger, 1968). This explains the high dispersion of FDX values in recent lysocline profiles (e.g., Parker and Berger, 1971), as well as those illustrated here (Fig. 4C). Consequently, FDX is of limited value for inferring or constraining lysocline profiles in the past. The same limitations apply to the planktonic foraminiferal susceptibility and to the benthic abundance. These two indicators reflect paleoclimatic and paleoecologic conditions at the sea surface and the seafloor together with dissolution, making them of limited value for inferring lysocline profiles in the past.

Implicitly assume that dissolution occurs at the seafloor. Nonetheless, Thunell and Honjo (1981) showed that substantial foraminiferal solution occurs in the fraction $<150 \mu \mathrm{m}$ during its transit through the water column. According to Berger and Piper (1972), a foraminifer test $100 \mu \mathrm{m}$ in diameter takes approximately 10 to 15 days to descend through $2.5 \mathrm{~km}$ of water. In Vanuatu, the travel time of foraminifer 


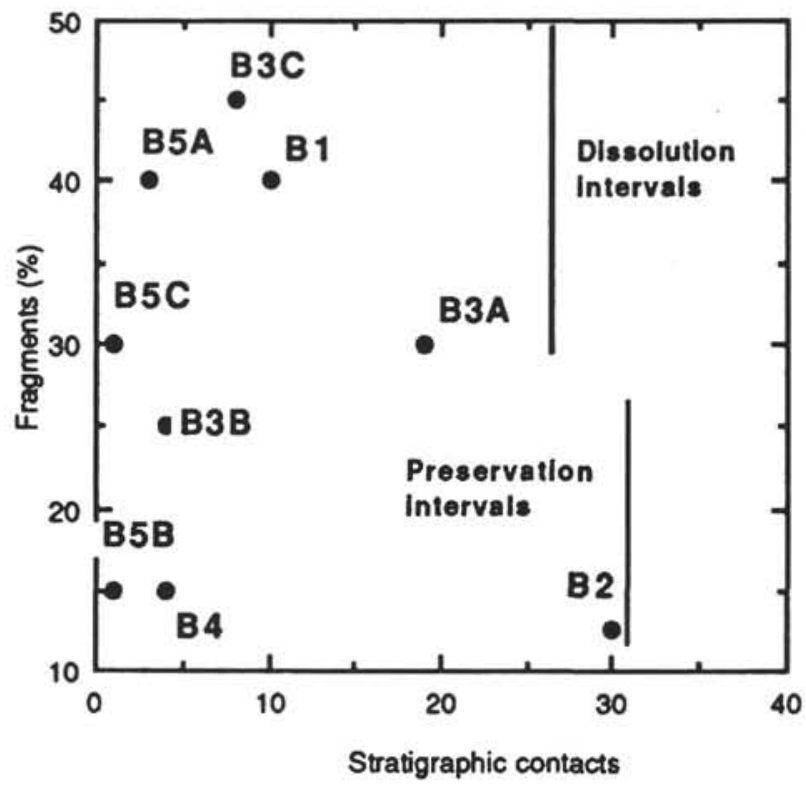

Figure 6. Hole 828A. Percentage of fragments vs. number of stratigraphic contacts. Note the lack of correlation.

tests could take longer because of the presence of a high-salinity layer $(\sim 36 \%)$ between 100 and $400 \mathrm{~m}$ (Tomczak and Hao, 1989). This longer transit time would favor dissolution.

As indicated above, Hole 828A resembles Pickering's Facies C1.1 and D1.2 (Pickering et al., 1989), indicating that these facies are the product of mud-dominated turbidity currents with "rapid deposition of silt grains and mud flocculations from suspension with no sizesorting either in the viscous sublayer or on the bed." It appears that most of the woody material, and possibly most of the mud, was transported as dilute mid-water flows along a density interface (the pycnocline?) that easily travelled across the trench to reach the NDR (Fig. 10). A simple test applying Stoke's law (Hsü, 1989) seems to support this possibility. Plagioclase $(G=2.67)$ and pyroxene $(G=3.5)$ are common minerals in the silt and very fine sand fraction of Hole $828 \mathrm{~A}$ (see Collot, Greene, Stokking, et al., 1992). If we use a 100$\mu \mathrm{m}$-diameter particle, a salinity of $36 \%$, and a temperature of $18^{\circ} \mathrm{C}$, then we have a transit time on the order of 10 days for plagioclase and of 7 days for pyroxene to reach the seafloor. In either case descent velocities are lower than $0.5 \mathrm{~cm} / \mathrm{s}$. Consequently, oceanic currents can easily keep silt particles, foraminifers, radiolarians, and woody material in suspension as they travel along mid-water flows. Accelerated dropping of these components to the seafloor could be enhanced by the formation of "marine snow." It has been suggested that in areas of high productivity interstitial $\mathrm{CO}_{2}$ favors the dissolution of planktonic foraminifers (Emerson and Bender, 1980). This mechanism seems to be of lesser importance in this area because the highest content of organic matter coincides with the preservation maxima. The same can be said of the suggested acidity generated by submarine weathering of volcanic ash, which seems to show the opposite pattern in the Vanuatu region: higher content of volcanic ash in Hole 832A coincides with a lower percentage of fragmentation compared to Hole $828 \mathrm{~A}$ where the content of volcanic ash is minimal.

The above-mentioned time lag of $\sim 8 \mathrm{k} . \mathrm{y}$. for the last glacial-interglacial interval agrees with the estimations of Farrell and Prell (1989) for the central equatorial Pacific. Peterson and Prell (1985) pointed out the differences between the inventory and circulation models to explain both time lags and out-of-phase dissolution patterns between the Atlantic and the Pacific oceans. Inventory models include that of Shackleton (1977) who suggested that preservation-dissolution of

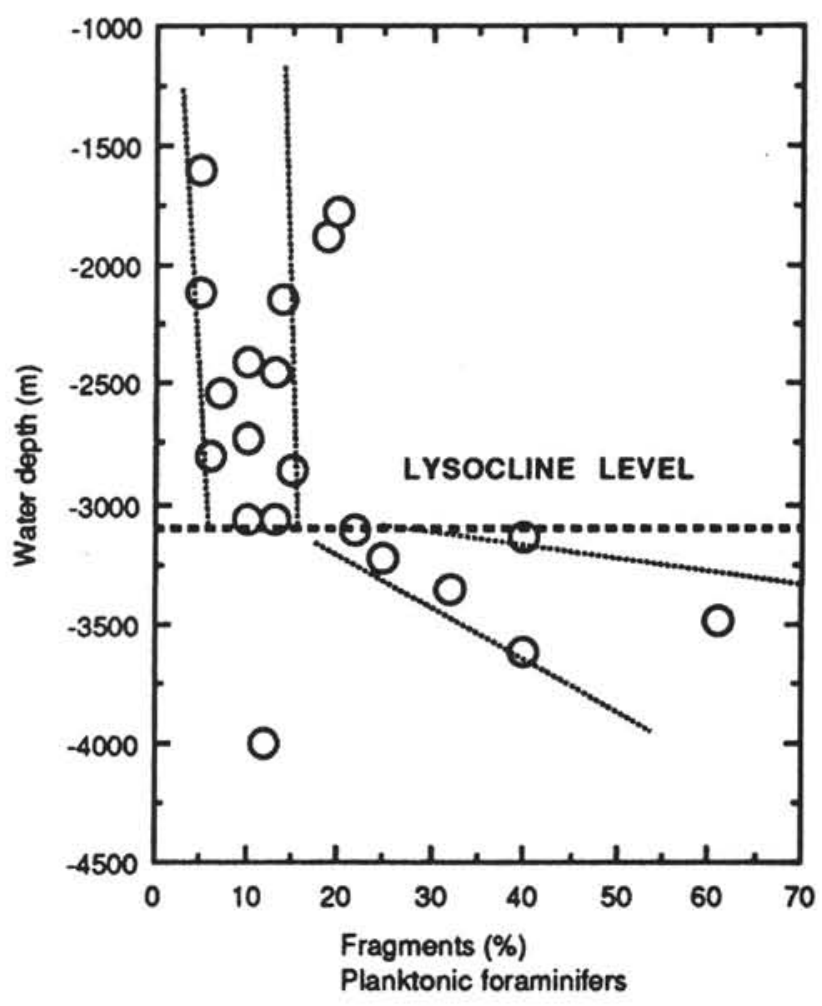

Figure 7. Modern foraminiferal lysocline profile for the area between $160^{\circ}$ and $180^{\circ} \mathrm{E}$, and $10^{\circ}$ and $30^{\circ} \mathrm{S}$ (see Table 5 for details). Counting error variation $\sim 5 \%$. Note the position of the lysocline level at $3.1 \mathrm{~km}$.

deep sea carbonates is due to the variations of terrestrial biomass during deglaciations and glaciations pumping out and injecting $\mathrm{CO}_{2}$ in the ocean. Other models include balances of phosphorous and organic carbon between the continental shelves and the deep sea (Broecker, 1982), and the rearrangements of nutrients between intermediate to deep depths during glacial/interglacial transitions (Broecker and Peng, 1987; Boyle, 1988). Circulation models, on the other hand, suggest that variations in the NADW (active only during interglacial intervals) may account for the differences in dissolution patterns between the Atlantic and the Pacific (e.g., Volat et al., 1980). I have mentioned the close similarities between Vanuatu and Ontong Java Plateau. Nonetheless in Hole 828A there is no time lag between ice volume minima and dissolution maxima as shown by Le and Shackleton (1992) for Ontong Java Plateau. Is this difference due to the high-resolution record from Vanuatu? If not, then local phenomena, including $\mathrm{CO}_{2}$ sinks (see map by Keeling, 1968), and the interplay of different water masses (e.g., the North Pacific vs. the Circumpolar Deep Water; Shackleton, 1985) could explain the difference, rather than carbonate supply variations that apparently were minor. In any case, dissolution of planktonic foraminifers in Hole 828A apparently responded (linearly?) to changes in atmospheric $\mathrm{CO}_{2}$ as recorded in the polar regions (e.g., Barnola et al., 1987). A satisfactory mechanism still must be proposed to explain this relationship and the out-of-phase record between fragmentation and stable isotope curves.

\section{Tectonic Implications}

The pattern of sedimentation rates of Hole $828 \mathrm{~A}$ can be explained by the progressive migration of the NDR toward Espiritu Santo Island. If we accept the present spreading rates of $\sim 13 \mathrm{~cm} / \mathrm{yr}$ as constant, then the NDR was approximately $32 \mathrm{~km}$ away from the New Hebrides Trench $250 \mathrm{ka}, 16 \mathrm{~km}$ at $120 \mathrm{ka}$, and $2.3 \mathrm{~km}$ at $18 \mathrm{ka}$ (Fig. 10). 
Table 5. List of data used to calculate the modern lysocline for the Vanuatu region. Planktonic foraminiferal fragmentation data on 23 core-tops.

\begin{tabular}{|c|c|c|c|c|}
\hline \multirow[b]{2}{*}{ Core } & \multicolumn{2}{|c|}{ Position } & \multirow{2}{*}{$\begin{array}{l}\text { Water } \\
\text { depth } \\
\text { (m) }\end{array}$} & \multirow{2}{*}{$\begin{array}{c}\text { Foraminiferal } \\
\text { fragmentation } \\
(\%)\end{array}$} \\
\hline & Latitude & Longitude & & \\
\hline NOVA-A 53 & $28^{\circ} 16^{\prime} \mathrm{S}$ & $161^{\circ} 31^{\prime} \mathrm{E}$ & 1607 & 5 \\
\hline RC10-139 & $03^{\circ} 02^{\prime} \mathrm{S}$ & $156^{\circ} 26^{\prime} \mathrm{E}$ & 1781 & 20 \\
\hline $\mathrm{RC} 12-115$ & $22^{\circ} 05^{\prime} \mathrm{S}$ & $173^{\circ} 16^{\prime} \mathrm{E}$ & 1875 & 19 \\
\hline RC13-39 & $15^{\circ} 53^{\prime} \mathrm{S}$ & $176^{\circ} 50^{\prime} \mathrm{E}$ & 2116 & 5 \\
\hline NOVA-A 36 & $21^{\circ} 41^{\prime} \mathrm{S}$ & $167^{\circ} 23^{\prime} \mathrm{E}$ & 2148 & 14 \\
\hline $\mathrm{RC} 12-103$ & $26^{\circ} 00^{\prime} \mathrm{S}$ & $179^{\circ} 44^{\prime} \mathrm{E}$ & 2401 & 10 \\
\hline $\mathrm{RC} 12-113$ & $24^{\circ} 53^{\prime} \mathrm{S}$ & $163^{\circ} 31^{\prime} \mathrm{E}$ & 2454 & 13 \\
\hline $\mathrm{RC} 9-124$ & $28^{\circ} 145^{\prime} \mathrm{S}$ & $172^{\circ} 36^{\prime} \mathrm{E}$ & 2540 & 7 \\
\hline $\mathrm{RC} 12-117$ & $16^{\circ} 25^{\prime} \mathrm{S}$ & $174^{\circ} 30^{\prime} \mathrm{E}$ & 2734 & 10 \\
\hline $\mathrm{RC} 13-40$ & $17^{\circ} 24^{\prime} \mathrm{S}$ & $176^{\circ} 41^{\prime} \mathrm{E}$ & 2798 & 6 \\
\hline $\mathrm{RC} 13-38$ & $14^{\circ} 31^{\prime} \mathrm{S}$ & $177^{\circ} 06^{\prime} \mathrm{E}$ & 2867 & 15 \\
\hline RC13-37 & $11^{\circ} 52^{\prime} \mathrm{S}$ & $177^{\circ} 25^{\prime} \mathrm{E}$ & 3067 & 13 \\
\hline NOVA-H 20 & $12^{\circ} 53^{\prime} \mathrm{S}$ & $176^{\circ} 39^{\prime} \mathrm{E}$ & 3063 & 10 \\
\hline $\mathrm{RC} 12-107$ & $26^{\circ} 00^{\prime} \mathrm{S}$ & $169^{\circ} 12^{\prime} \mathrm{E}$ & 3115 & 22 \\
\hline $\mathrm{RC} 12-116$ & $19^{\circ} 28^{\prime} \mathrm{S}$ & $175^{\circ} 06^{\prime} \mathrm{E}$ & 3136 & 40 \\
\hline $\mathrm{RC1} 2-118$ & $12^{\circ} 59^{\prime} \mathrm{S}$ & $174^{\circ} 01^{\prime} \mathrm{E}$ & 3233 & 25 \\
\hline $\mathrm{RC} 12-108$ & $26^{\circ} 02^{\prime} \mathrm{S}$ & $165^{\circ} 49^{\prime} \mathrm{E}$ & 3354 & 32 \\
\hline NOVA-HV 15 & $28^{\circ} 10^{\prime} \mathrm{S}$ & $171^{\circ} 12^{\prime} \mathrm{E}$ & 3489 & 61 \\
\hline NOVA-A 40 & $23^{\circ} 00^{\prime} \mathrm{S}$ & $164^{\circ} 58^{\prime} \mathrm{E}$ & 3617 & 40 \\
\hline $\mathrm{RC} 12-114$ & $24^{\circ} 46^{\prime} \mathrm{S}$ & $170^{\circ} 26^{\prime} \mathrm{E}$ & 3997 & 12 \\
\hline $\mathrm{RC} 12-104$ & $26^{\circ} 04^{\prime} \mathrm{S}$ & $176^{\circ} 42^{\prime} \mathrm{E}$ & 4330 & 0 \\
\hline $\mathrm{RC} 12-105$ & $26^{\circ} 04^{\prime} S$ & $176^{\circ} 42^{\prime} \mathrm{E}$ & 4356 & 0 \\
\hline $\mathrm{RC} 12-106$ & $26^{\circ} 01^{\prime} \mathrm{S}$ & $174^{\circ} 01^{\prime} \mathrm{E}$ & 4669 & 0 \\
\hline
\end{tabular}

Note: Counting error $\sim 5 \%$, on the $>149 \mu \mathrm{m}$ size fraction.

As subduction progressed, the sedimentation regime changed from pelagic to hemipelagic over the NDR. Turbiditic clouds moving as mid-water flows reached the site about $125 \mathrm{ka}$, releasing their silt, clay, and woody material load. The existence at present of a salinity maximum layer $(\sim 36 \%)$ between 100 to $400 \mathrm{~m}$ (Tomczak and Hao, 1989) supports this interpretation as strong density contrasts favor the existence of mid-water flows (Pickering et al., 1989). Bottom turbidites apparently were not effective until later when Site 828 approached the New Hebrides Trench. This event coincided with the LGM when the eustatic drop in sea level favored the high-energy erosion of the island, and worldwide oceanic conditions were more dynamic (higher storm activity). At this time, turbidite clouds were able to bypass the New Hebrides Trench and terrigenous input became important. The increase in sedimentation rates appears to result from both proximity to, and upheaval of, the island.

\section{CONCLUSIONS}

1. Pelagic to hemipelagic sediments of the uppermost $61.9 \mathrm{~m}$ of Hole $828 \mathrm{~A}$ were deposited during isotopic Stages 7 to 1 ( $\sim 250 \mathrm{ka}$ to present). The high-resolution pattern of foraminiferal fragmentation in Hole 828A shows the record of disso lution Intervals B1 to B5C. This record is very similar to the $\delta^{18} \mathrm{O}$ stack (Martinson et al., 1987) and the atmospheric record of $\mathrm{CO}_{2}$ as recorded in ice cores (Barnola et al., 1987) and is out of phase with the $\delta^{18} \mathrm{O}$ record of $G$. sacculifer

2. Comparing dissolution minima and maximum ice volume, the dissolution record is lagging the isotopic record by approximately 8 k.y. in accord to previous studies for the equatorial Pacific (e.g., Farrell and Prell, 1989). No lag was found between dissolution maxima and minimum ice volumes (different from the Ontong Java Plateau where a 6- to 20-k.y. lag has been recorded, Le and Shackleton, 1992). Local $\mathrm{CO}_{2}$ sinks and the interplay between intermediate and deep water masses may explain the difference.

3. Fragmentation of planktonic foraminifers is a more sensitive dissolution indicator than planktonic foraminiferal susceptibility, the foraminiferal dissolution index (Berger, 1968), the abundance of benthic foraminifers, and $\mathrm{CaCO}_{3}$ content. A modern lysocline for the area is found at $3.1 \mathrm{~km}$ below sea level (foraminiferal lysocline) compared to west of Vanuatu where it is shallower (a near continent type). A $20 \%$ threshold in foraminiferal fragmentation indicates past lysocline fluctuations.

4. The past lysocline was deeper (than $3086 \mathrm{~m}$ ) during intervals of dissolution minima, and ranged from 2550 to $3000 \mathrm{~m}$ during intervals of dissolution maxima.

5. Site 828 is progressively affected by mid-water flows and turbidites that become important from $125 \mathrm{ka}$ to present. Dilution by terrigenous material affected the lysocline profile that evolved from an open ocean to a near continent type.

6 . The very high sedimentary record found in Hole 828A opens new and interesting possibilities for high-resolution paleoceanographic and paleoclimatic studies, either in this hole or on further localities west of this site where turbidites must occur in lower proportion. This equally applies to analogous seaward trench localities all over the world previously considered as unsuitable for this type of study (Ruddiman, 1977).

7. The complete $\delta^{18} \mathrm{O}$ record of Hole $828 \mathrm{~A}$ is expected to provide a more precise chronostratigraphic framework and new insights into dissolution cyclicity.

\section{ACKNOWLEDGMENTS}

I thank Dr. Patrick De Deckker for scientific advice and for critical review of the manuscript. Dr. John Tipper made valuable suggestions and Dr. Richard Gillespie prepared samples for AMS and arranged the datings at DSIR (Nuclear Science Group, New Zealand). Dr. Allan Chivas and Mr. Joe Cali performed the stable isotope analyses at the Research School of Earth Sciences (The Australian National University). Dr. Jörn Thiede kindly provided the core-top samples. Thoughtful reviews of the manuscript by Drs. John Chappell, André Droxler, Gary Greene, Michael Ayress, and an anonymous reviewer are greatly appreciated. I wish to acknowledge the financial help of the Australian ODP secretariat (Dr. Tony Crawford) to participate on Leg 134 and to attend the post-cruise meeting. This paper is part of my Ph.D. thesis project on the paleoceanography of the southwest Pacific during the Brunhes Chron (Australian National University Ph.D. scholarship).

\section{REFERENCES*}

Anderson, D.M., Prell, W.L., Barratt, N.J., 1989. Estimates of sea surface temperature in the Coral Sea at the Last Glacial Maximum. Paleoceanography, 4:615-627.

Arrhenius, G., 1952. Sediment cores from the east Pacific. Rep. Swed. DeepSea Exped. 1947-1948, 5.

, 1988. Rate of production, dissolution and accumulation of biogenic solids in the ocean. Palaeogeogr, Palaeoclimatol., Palaeoecol., 67:119-146.

Bard, E., Hamelin, B., Fairbanks, R.G., and Zinder, A., 1990. Calibration of the ${ }^{14} \mathrm{C}$ time-scale over the past 30,000 years using mass spectrometric U-Th ages from Barbados corals. Nature, 345:405-410.

Barnola, J.M., Raynaud, D., Korotkevich, Y.S., and Lorius, C., 1987. Vostok ice core provides 160,000 -year record of atmospheric $\mathrm{CO}_{2}$. Nature, 329:408-414.

Bé, A.W.H., 1977. An ecological, zoogeographic and taxonomic review of Recent planktonic foraminifera. In Ramsay, A.T.S. (Ed.), Oceanic Micropaleontology (Vol. 1): London (Academic Press), 1-100.

Berger, W.H., 1968. Planktonic foraminifera: selective solution and paleoclimatic interpretation. Deep-Sea Res. Part A, 15:31-43.

1970. Planktonic foraminifera: selective solution and the lysocline. Mar. Geol., 8:111-138.

- 1977. Deep-sea carbonate and deglaciation preservation spike in pteropods and foraminifera. Nature, 269:301-304.

Berger, W.H., Bonneau, M.-C., and Parker, F.L., 1982. Foraminifera on the deep-sea floor: lysocline and dissolution rate. Oceanol. Acta, 5:249-258.

\footnotetext{
* Abbreviations for names of organizations and publications in ODP reference lists follow the style given in Chemical Abstracts Service Source Index (published by American Chemical Society).
} 
Berger, W.H., and Killingley, J.S., 1977. Glacial-Holocene transition in deepsea carbonates: selective dissolution and the stable isotope signal. Science, 197:563-566.

Berger, W.H., and Piper, D.J.W., 1972. Planktonic foraminifera: differential settling, dissolution and redeposition. Limnol. Oceanogr., 17:275-287.

Boyle, E.A., 1988. Vertical oceanic nutrient fractionation and glacial/interglacial $\mathrm{CO}_{2}$ cycles. Nature, 331:55-56.

Broecker, W.S., 1971. Calcite accumulation rates and glacial to interglacial changes in oceanic mixing. In Turekian, K.K. (Ed.), The Late Cenozoic Glacial Ages: New Haven, CT (Yale Univ. Press), 239-265.

, 1982. Glacial to interglacial changes in ocean chemistry. Prog. Oceanogr., 11:151-197.

Broecker, W.S., and Peng, T.H., 1982. Tracers in the Sea: New York (LamontDoherty Geological Observatory, Columbia Univ.).

, 1987. The role of $\mathrm{CaCO}_{3}$ compensation in the glacial to interglacial atmospheric $\mathrm{CO}_{2}$ change. Global Biogeochem. Cycles, 1:15-29.

Broecker, W.S., Trumbore, S., Bonani, G., Wolfi, W., and Klas, M., 1989. Anomalous AMS radiocarbon ages for foraminifera from high-depositionrate ocean sediments. Radiocarbon, 31:157-162.

CLIMAP Project Members, 1981. Seasonal reconstructions of the Earth's surface at the last glacial maximum. Geol. Soc. Am., Map and Chart Ser., MC36:1-18.

Collot, J.-Y., Greene, H.G., Stokking, L.B., et al., 1992. Proc. ODP, Init. Repts., 134: College Station, TX (Ocean Drilling Program).

Dean, W.E., Gardner, J.V., and Cepek, P., 1981. Tertiary carbonate-dissolution cycles on the Sierra Leone Rise, eastern Equatorial Atlantic Ocean. Mar. Geol., 39:81-101.

De Deckker, P., Correge, T., and Head, J., 1991. Late Pleistocene record of cyclic eolian activity from tropical Australia suggesting the Younger Dryas is not an unusual event. Geology, 19:602-605.

Diester-Haass, L., 1991. Rhythmic carbonate content variations in Neogene sediments above the oceanic lysocline. In Einsele, G., Ricken, W., and Seilacher, A. (Eds.), Cycles and Events in Stratigraphy: Berlin (SpringerVerlag), 94-109.

Dimberline, A.J., and Woodcock, N.H., 1987. The southwest margin of the Wenlock turbidite system, Mid-Wales. Geol. J., 22:61-71.

Dott, R.H., Jr., 1983. Episodic sedimentation-How normal is average? How rare is rare? Does it matter? J. Sediment. Petrol., 53:5-23.

Einsele, G., 1982a. General remarks about the nature, occurrence, and recognition of cyclic sequences (periodites). In Einsele, G., and Seilacher, A. (Eds.), Cyclic and Event Stratification: Berlin (Springer-Verlag), 3-7.

, 1982b. Limestone-marl cycles (periodites): diagnosis, significance, causes-a review. In Einsele, G., and Seilacher, A. (Eds.), Cyclic and Event Stratification: Berlin (Springer-Verlag), 8-53.

Einsele, G., and Ricken, W., 1991. Limestone-marl alternation-an overview. In Einsele, G., Ricken, W., and Seilacher, A. (Eds.), Cycles and Events in Stratigraphy: Berlin (Springer-Verlag), 23-47.

Emerson, S., and Bender, M., 1981. Carbon fluxes at the sediment-water interface of the deep-sea: calcium carbonate preservation. J. Mar. Res., $39: 139-162$.

Emery, W.J., and Meincke, J., 1986. Global water masses: summary and review. Oceanol. Acta, 9:383-391.

Erez, J., Almogi-Labin, A., and Avraham, S., 1991. On the life history of planktonic foraminifera: lunar reproduction cycle in Globigerinoides sacculifer (Brady). Paleoceanography, 6:295-306.

Farrell, J.W., and Prell, W.L., 1989. Climatic change and $\mathrm{CaCO}_{3}$ preservation: an 800,000 year bathymetric reconstruction from the central equatorial Pacific Ocean. Paleoceanography, 4:447-466.

Gray, W.M., 1968. Global view of the origin of tropical disturbances and storms. Mon. Weather Rev., 96:669-700.

Hays, J.D., Saito, T., Opdyke, N.D., and Burckle, L.H., 1969. Pliocene-Pleistocene sediments of the equatorial Pacific: their paleomagnetic, biostratigraphic, and climatic record. Geol. Soc. Am. Bull., 80:1481-1513.

Howorth, R., and Greene, G., 1991. Effects of cyclones Ursula, Carlotta and Uma in the Port Villa-Mele Bay area, Vanuatu. In Workshop on Water Processes in the South Pacific Island Nations, Lae, Papua New Guinea, 1-8 October 1987. SOPAC Tech. Bull., 7:123-124.

Hsü, K., 1989. Physical Principles of Sedimentology: Berlin (Springer-Verlag).

Huang, T.C., 1980. A volcanic sedimentation model: implication of processes and responses of deep-sea ashes. Mar. Geol., 38:103-122.

Keeling, C.D., 1968. Carbon dioxide in surface ocean waters, 4: Global distributions. J. Geophys. Res., 14:4543-4553.
Kudrass, H.R., Erlenkeuser, H., Vollbrecht, R., and Weiss, W., 1991. Global nature of the Younger Dryas cooling event inferred from oxygen isotope data from Sulu Sea cores. Nature, 349:406-409.

Le, J., and Shackleton, N.J., 1992. Carbonate dissolution fluctuations in the western equatorial Pacific during the late Quaternary. Paleoceanography, $7: 21-42$.

Linsley, B.K., and Thunell, R.C., 1990. The record of deglaciation in the Sulu Sea: evidence for the Younger Dryas event in the western tropical Pacific. Paleoceanography, 5:1025-1039.

Luz, B., 1973. Stratigraphic and paleoclimatic analysis of Late Pleistocene tropical southeast Pacific cores. Quat. Res. (N.Y.), 3:56-72.

Luz, B., and Shackleton, N.J., 1975. $\mathrm{CaCO}_{3}$ solution in the tropical east Pacific during the past 130,000 years. Spec. Publ. Cushman Found. Foraminiferal Res., 13:142-150.

Martinson, D.G., Pisias, N.G., Hays, J.D., Imbrie, I., Moore, T.C., Jr., and Shackleton, N.J., 1987. Age dating and the orbital theory of the ice-ages: development of a high-resolution 0 to 300,000-year chronostratigraphy. Quat. Res. (N.Y.), 27:1-29.

Moore, T.C., Burckle, L.H., Geitzenauer, K., Luz, B., Molina-Cruz, A., Robertson, J.H., Sachs, H., Sancetta, C., Thiede. J., Thompson, P., and Wenkam, C. 1980. The reconstruction of sea surface temperatures in the Pacific Ocean of 18,000 BP. Mar. Micropaleontol., 5:215-247.

Moore, T.C., Pisias, N.G., and Heath, G.R., 1977. Climate changes and lags in Pacific carbonate preservation, sea surface temperature and global ice volume. In Malahoff, A., and Anderson, N. (Eds.), The Fate of Fossil Fuel $\mathrm{CO}_{2}$ in the Oceans: New York (Plenum), 145-165.

Parker, F.L., and Berger, W.H., 1971. Faunal and solution patterns of planktonic Foraminifera in surface sediments of the South Pacific. Deep-Sea Res. Part A, 18:73-107.

Peterson, L.C., and Prell, W.L., 1985. Carbonate preservation and rates of climatic change: an $800 \mathrm{kyr}$ record from the Indian Ocean. In Sundquist, E.T., and Broecker, W.S. (Eds.), The Carbon Cycle and Atmospheric $\mathrm{CO}_{2}$ : Natural Variations Archean to Present: Am. Geophys. Union Monogr., 32:251-270.

Pickering, K.T., Hiscott, R.N., and Hein, F.J., 1989. Deep Marine Environments: Clastic Sedimentation and Tectonics: London (Unwin Hyman).

Rotschi, H., and Lemasson, L., 1967. Oceanography of the Coral and Tasman Seas, Oceanogr. Mar. Biol., 5:49-97.

Ruddiman, W.F., 1977. Investigations of Quaternary climate based on planktonic Foraminifera. In Ramsay, A.T.S. (Ed.), Oceanic Micropaleontology: New York (Academic Press), 1:101-162.

Shackleton, N.J., 1977. Carbon-13 in Uvigerina: tropical rainforest history and the equatorial Pacific carbonate dissolution cycles. In Andersen, N.R., and Malahoff, A. (Eds.), The Fate of Fossil Fuel $\mathrm{CO}_{2}$ in the Oceans: New York (Plenum), 401-427. $66: 292$

Shackleton, N.J., and Opdyke, N.D., 1973. Oxygen isotope and paleomagnetic stratigraphy of equatorial Pacific core V28-238: oxygen isotope temperatures and ice volumes on a $10^{5}$ year and $10^{6}$ year scale. Quat. Res. (N.Y.), 3:39-55.

1976. Oxygen-isotope and paleomagnetic stratigraphy of Pacific Core V28-239: late Pliocene to latest Pleistocene. In Cline, R.M., and Hays, J.D. (Eds.), Investigations of Late Quaternary Paleoceanography and Paleoclimatology. Mem.-Geol. Soc. Am., 145:449-464.

Thompson, P.R., 1976. Planktonic foraminiferal dissolution and the progress towards a Pleistocene equatorial Pacific transfer function. J. Foraminiferal Res., 6:208-227.

Thompson, P.R., Duplessy, J.C., and Bé, A.H., 1979. Disappearance of pinkpigmented Globigerinoides ruber at $120,000 \mathrm{yr}$ BP in the Indian and Pacific Oceans. Nature, 280:554-558.

Thompson, P.R., and Saito, T., 1974. Pacific Pleistocene sediments: planktonic foraminifera dissolution cycles and geochronology. Geology, 2:333-335.

Thunell, R.C., 1976. Optimum indices of calcium carbonate in deep-sea sediments. Geology, 4:525-528.

Thunell, R.C., and Honjo, S., 1981. Planktonic foraminiferal flux to the deep ocean: sediment trap results from the tropical Atlantic and the central Pacific. Mar. Geol., 40:237-253.

Thunell, R.C., Qingmin, M., Calvert, S.E., and Pedersen, T.F., 1992. GlacialHolocene biogenic sedimentation patterns in the South China Sea: productivity variations and surface water $\mathrm{pCO}_{2}$. Paleoceanography, $7: 143-162$. 
Tomczak, M., and Hao, D., 1989. Water masses in the thermocline of the Coral Sea. Deep-Sea Res. Part A, 36:1503-1514.

Volat, J.-L., Pastouret, L., and Vergnaud-Grazzini, C., 1980. Dissolution and carbonate fluctuations in Pleistocene deep-sea cores: a review. Mar. Geol., 34:1-28.

Wu, G., and Berger, W.H., 1989. Planktonic foraminifera: differential dissolution and the Quaternary stable isotope record in the west-equatorial Pacific. Paleoceanography, 4:181-198.

Wu, G., Herguera, J.C., and Berger, W.H., 1990. Differential dissolution: modification of late Pleistocene oxygen isotope records in the western equatorial Pacific. Paleoceanography, 5:581-594.
Wu, G., Yasuda, M.K., and Berger, W.H., 1991. Late Pleistocene carbonate stratigraphy on Ontong-Java Plateau in the western equatorial Pacific. Mar. Geol., 99:135-150.

Wyrtki, K., 1962. The subsurface water masses in the western South Pacific Ocean. Aust. J. Mar. Freshwater Res., 13:18-47.

Date of initial receipt: 2 April 1992

Date of acceptance: 19 November 1992

Ms 134SR-012

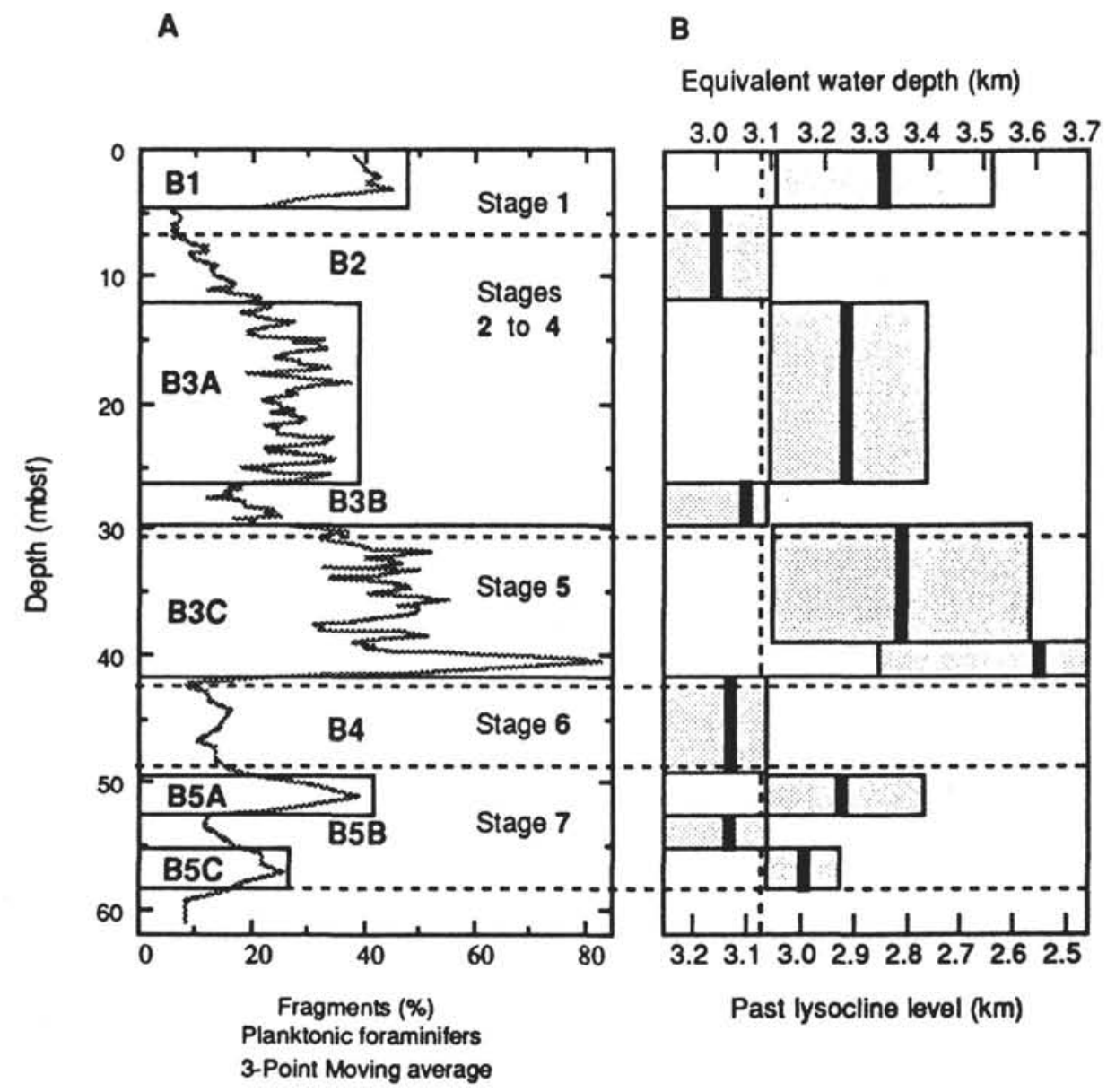

Figure 8. Hole 828A. (A) Percentage of fragments (3-point moving average) vs. (B) equivalent water depth (upper scale) and the lysocline level in the past (lower scale). Shaded areas indicate error bars; black lines indicate the approximate position of the lysocline level. Error bars on the left of the present seafloor depth (dashed line) extend to at least $1.5 \mathrm{~km}$ (see Fig. 7 for comparison). Lysocline level positions for preservation intervals are uncertain and indicated only as relative values. 


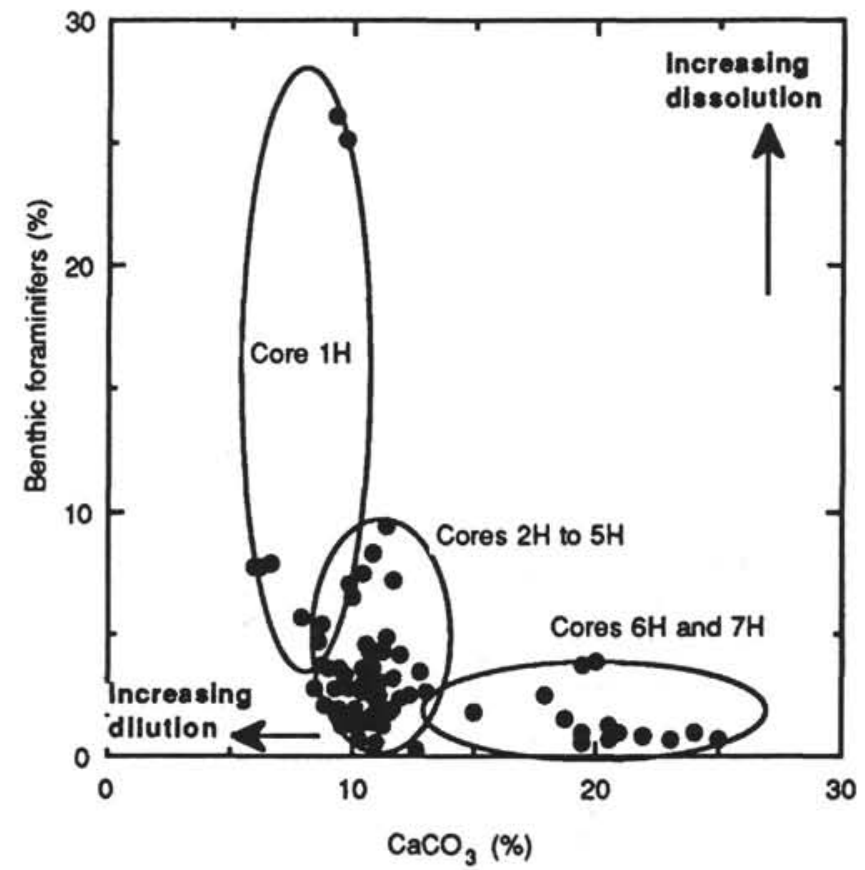

Figure 9. Hole 828A. Calcium carbonate content vs. carbonate dissolution (percentage of benthic foraminifers expressed as benthic/[benthic + planktonic foraminifers]). Note increasing dilution and dissolution effects from Core $139-828 \mathrm{~A}-7 \mathrm{H}$ to $-1 \mathrm{H}$.

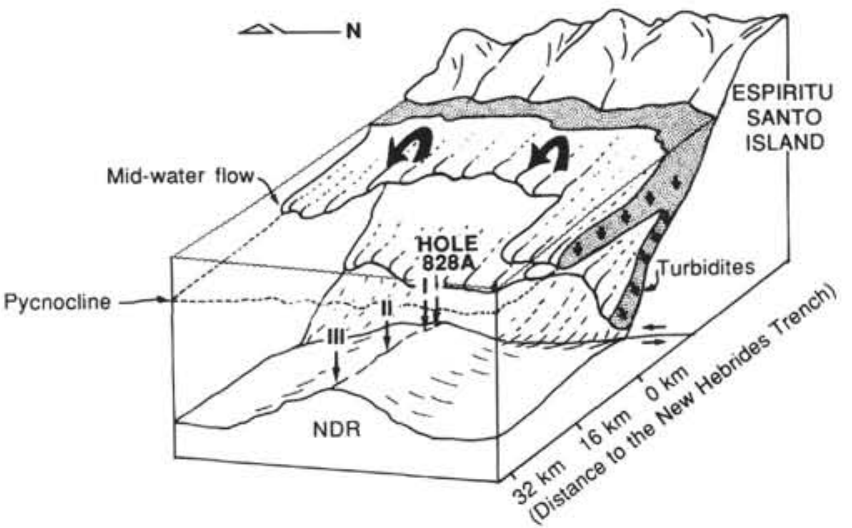

Figure 10. Hole 828A. Sedimentation model for western Vanuatu. The paleolocation of Site 828 is illustrated at three different times: Termination III, II, and $\mathrm{I}$, when the distance to the trench was $\sim 32, \sim 16$, and $\sim 2.4 \mathrm{~km}$, respectively. Mid-water flows, activated by the frequent storms of the area, moved along a density contrast (the high-salinity layer found between 100 and $400 \mathrm{~m}$ ). True turbidites appear to affect Site 828 around Termination I. Sedimentation model adapted from a drawing by Dimberline and Woodcock (1987). 